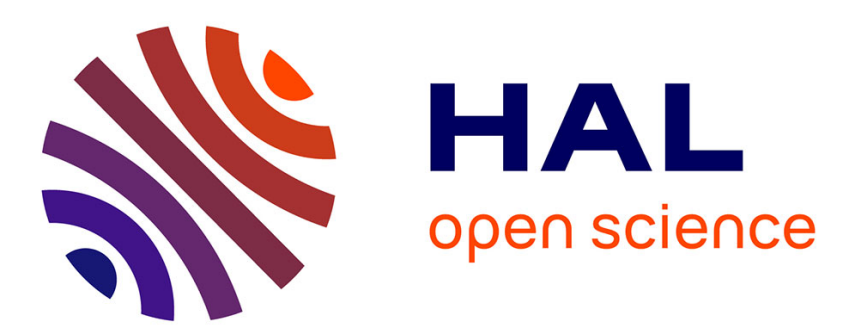

\title{
Birthplace diversity and economic growth: evidence from the US states in the Post-World War II period
}

Frédéric Docquier, Riccardo Turati, Jérôme Valette, Chrysovalantis Vasilakis

\section{To cite this version:}

Frédéric Docquier, Riccardo Turati, Jérôme Valette, Chrysovalantis Vasilakis. Birthplace diversity and economic growth: evidence from the US states in the Post-World War II period. Journal of Economic Geography, 2020, 20 (2), pp.321-354. 10.1093/jeg/lbz016 . hal-02865160

\section{HAL Id: hal-02865160 \\ https://hal.science/hal-02865160}

Submitted on 1 Apr 2021

HAL is a multi-disciplinary open access archive for the deposit and dissemination of scientific research documents, whether they are published or not. The documents may come from teaching and research institutions in France or abroad, or from public or private research centers.
L'archive ouverte pluridisciplinaire HAL, est destinée au dépôt et à la diffusion de documents scientifiques de niveau recherche, publiés ou non, émanant des établissements d'enseignement et de recherche français ou étrangers, des laboratoires publics ou privés. 


\title{
Birthplace Diversity and Economic Growth: Evidence from the US States in the Post-World War II Period*
}

\author{
Frédéric Docquier ${ }^{\mathrm{a}, \mathrm{b}}$, Riccardo Turati ${ }^{\mathrm{b}}$, Jérôme Valette ${ }^{\mathrm{c}}$, and Chrysovalantis \\ Vasilakis $^{\mathrm{b}, \mathrm{d}}$ \\ ${ }^{\mathrm{a}}$ LISER, Luxembourg Institute of Socio-Economic Research (Luxembourg) \& FNRS (Belgium) \\ b IRES, Université Catholique de Louvain (Belgium) \\ ${ }^{\mathrm{c}}$ CES, University of Paris 1 Panthéon-Sorbonne (France) \\ dBangor Business School (United Kingdom) \& IZA (Germany)
}

\begin{abstract}
This paper empirically investigates the impact of birthplace diversity on economic growth. We use panel data on US states over the 1960-2010 period. This rich data set allows us to better deal with endogeneity issues and to conduct a large set of robustness checks. Our results suggest that diversity among college-educated immigrants positively affects economic growth. We provide converging evidence pointing at the existence of skill complementarities between workers trained in different countries. These synergies result in better labor market outcomes for native workers and in higher productivity in the $R \& D$ sector. The gains from diversity are maximized when immigrants originate from economically or culturally distant countries (but not both), and when they acquired part of their secondary education abroad and their college education in the US. Overall, a $10 \%$ increase in high-skilled diversity raises GDP per capita by about $6 \%$. On the contrary, low-skilled diversity has insignificant effects.
\end{abstract}

Keywords: Immigration Culture, Birthplace Diversity Growth.

JEL codes: F22 J61

${ }^{*}$ We are grateful to Simone Bertoli, Jean-Louis Combes, Oded Galor, William Kerr and Hillel Rapoport for helpful comments. This paper has also benefited from discussions at the SEPIO Workshop on Cultural Diversity (Paris, May 2016), at the Workshop on "The Importance of Elites and their Demography for Knowledge and Development" (Louvain-la-Neuve, June 2016), at the XII Migration Summer School at EUI (Florence, July 2016) and at the 7th International Conference "Economics of Global Interactions: New Perspectives on Trade, Factor Mobility and Development" (Bari, September 2016). The first author is grateful for the financial support from the Fonds spéciaux de recherche granted by the National Fund for Scientific Research (FNRS grant n. 14679993). The usual disclaimers apply. 


\section{Introduction}

Patterns of international migration to industrialized countries have drastically changed since World War II (WW2). On average, the share of foreigners in the population of high-income countries increased from 4.9 to 11.7\% between 1960 and 2010 (Özden et al. 2011). This phenomenon has similarly affected the United States (from 5.4 to 13.6\%), the members of the European Union (from 3.9 to 12.2\%), Canada and Australia (from 15 to $22 \%$ ). In addition, this change has been predominantly driven by immigration from developing countries; the share of South-North immigrants in the population of high-income countries increased from 2.0 to $8.7 \%$ in half a century 11 The literature investigating the economic impact of immigration on the United States and on other host countries has grown rapidly in the past decades (Borjas, 1994). It sheds light on how the welfare of natives and economic outcomes are affected by the number and characteristics of immigrants. Among the multiple transmission channels, the labor market, fiscal, and market size effects of migration have been abundantly studied, and a growing consensus on how to formalize and quantify them has gradually emerged 2 Nevertheless, the growing inflow of people coming from geographically, economically and culturally distant countries raises specific issues, as it has conceivably brought different skills and abilities, but also different social values and norms, or different ways of thinking. The macroeconomic effects of birthplace diversity, as well as the channels through which they materialize, are still uncertain.

This paper empirically investigates the impact of birthplace diversity on the macroeconomic performance of US states (proxied by their level of GDP per capita) since WW2. Our analysis combines three innovative features. First, we rely on panel data available for a large number of regions over a long period. Our sample covers all US states over the 1960-2010 period in ten-year intervals. This rich data set allows us to conduct a large number of robustness checks, and to better deal with unobserved heterogeneity and other endogeneity issues. This is crucial because economic prosperity and the degree of diversification in production are likely to attract people from different cultural origins (see Alesina and La Ferrara, 2005), implying that causation is hard to establish in a cross-sectional setting. To control for unobserved heterogeneity and reverse causation biases, our paper uses a great variety of geographic and time fixed effects, and combines various instrumentation strategies that have been used in the existing literature. Second, we systematically investigate whether the economic effect of birthplace diversity is heterogeneous across skill groups. The costs and benefits from diversity are likely to vary with the levels of task complexity and interaction between workers; meanwhile, high-skilled and low-skilled immigrants are likely to heterogeneously propagate social values and norms across borders. We account for this by using skill-specific measures of birthplace diversity. In addition, taking advantage of the availability of microdata, we compute our indices of diversity for different

\footnotetext{
${ }^{1}$ Immigration from developing countries accounts for $98 \%$ of the 1960-2010 rise in immigration to highincome countries, for $80 \%$ in the European Union, for $120 \%$ in the United States, and for $150 \%$ in Australia and Canada. Trends in immigration to the US are presented in Figure A1 in the Appendix.

${ }^{2}$ See among others, Borjas (2003), Card (2009), Ottaviano and Peri (2012), Storesletten (2000), Dustmann and Frattini (2014), Iranzo and Peri (2010), di Giovanni et al. (2015), Aubry et al. (2016), Burzyński et al. (2018).
} 
groups of immigrants (by age of entry or by legal status). Third, we conduct an exploratory analysis of the channels of transmission through which birthplace diversity affects economic growth, and of the conditions under which the growth-enhancing effect of diversity is maximized. To do so, we test whether diversity affects the alternative outcomes of interest or intermediate variables influencing the level and/or growth rate of GDP per capita. We also use augmented diversity indices to investigate whether the gains from diversity are influenced by the cultural and economic distances between the origin countries and the US.

Our paper belongs to a recent and growing strand of literature, which considers (i) that culture can be a feature differentiating individuals in terms of their attributes, (ii) that such a differentiation may have positive or negative effects on people's productivity, and (iii) that culture is affected by the country of birth (which determines the language and social norms individuals were exposed to in their youth, the education system, etc.). On the one hand, homogeneous people are more likely to get along well, which implies that cultural diversity may reduce trust or increase communication, cooperation and coordination costs. Moreover, diversity can also be the source of epidemiological effects if immigrants convey the cultural, social and institutional norms prevailing in their origin countries, as argued by Collier (2013) and Borjas (2015). On the other hand, cultural diversity also enhances complementarities across diverse productive traits, stimulating innovations and the collective ability to solve problems since a more diverse group is likely to bring varied solutions to the same problem. Evidence of such costs and benefits has been found in micro studies. For example, Parrotta et al. (2014) investigate the effect of different forms of diversity (by education, age group, and nationality) on the productivity of Danish firms, using a matched employeremployee database. They find a negative effect of worker diversity by nationality on productivity. On the contrary, Ozgen et al. (2014) find that birthplace diversity increases the likelihood of innovations using Dutch firm-level survey data, and Boeheim et al. (2012) find a positive effect of diversity on productivity using Austrian data. In the same vein, Kahane et al. (2013) find a positive effect of diversity on hockey team performance using data from the NHL (the North American National Hockey League).

Contrary to the firm-level approach, the analyses conducted at the macro level account for interdependencies between firms, industries, and/or regions. Existing studies have identified significant and positive effects of cultural diversity on comparative development and on disparities in economic performance across modern societies $3^{3}$ Ottaviano and Peri (2006) use US data by metropolitan area over the 1970-1990 period. In their (log of) wage regressions, the coefficient of diversity varies between 0.7 and 1.5. Ager and Brückner (2013) use US data by county during the 1870-1920 period: the coefficient of diversity in the output per capita regressions varies between 0.9 and 2.0. In these two studies, endogeneity issues are solved by using a shift-share method, i.e. computing the diversity index on the basis of predicted immigrant stocks. More precisely, the change in immigration to a region is predicted as the product of the global change in immigration

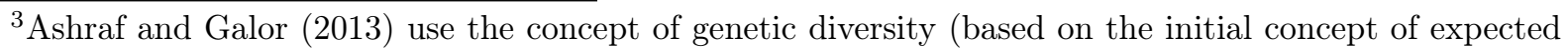
heterozygosity, that is the probability of selecting two random people from the population who are genetically different) and find a strong hump-shaped relation with the level of development around the years 1500 and 2000 .
} 
to the US by the regional share in total immigration in the initial year. A more recent study accounting for the education level of immigrants is that of Alesina et al. (2016); it is the most similar to ours. They use cross-sectional data on immigration stocks by education level for a large set of countries in the year 2000, and develop a pseudo-gravity first-stage model to predict migration stocks and birthplace diversity indices. They also identify a positive effect of birthplace diversity in countries with a GDP per capita above the median, and a stronger effect for diversity among college-educated workers. The effect of diversity on the log of GDP per capita is around 0.1 when computed on low-skilled workers, while the effect of diversity among the highly skilled varies between 0.2 and 0.3. Similarly, Suedekum et al. (2014) use annual German data by region from 1995 to 2006. Over this short period, they find a weaker effect of diversity on the log of German wages (about 0.1 for diversity among high-skilled foreigners, and 0.04 for diversity among the low skilled) when fixed effects and IV methods are used.

Our empirical analysis relies on high-quality US census data by state over the 1960-2010 period. The choice of this period is guided by the 1965 amendments to the Immigration and Nationality Act, which led to an upward surge in U.S. immigration and diversity (as in Ottaviano and Peri (2006)). Birthplace diversity is almost perfectly correlated with the state-wide proportion of immigrants, which has increased threefold since 1960 in all skill groups. It is thus statistically impossible to disentangle the effects of birthplace diversity from those of the size of immigration. For this reason, we opt for a benchmark model that includes the immigration rate and a birthplace diversity index pertaining to the immigrant population. In line with Alesina et al. (2016) and Suedekum et al. (2014), we find that diversity among college-educated immigrants is positively associated with the level of GDP per capita; however, diversity among less educated immigrants has insignificant (or weakly significant and much smaller) effects. Another remarkable result is that the estimated coefficient is divided by four when geographic and year fixed effects are included. Still, our estimates are greater than those reported in Alesina et al. (2016) and Suedekum et al. (2014): a $10 \%$ increase in highskilled diversity raises GDP per capita by about $6 \%$. There is converging evidence pointing at the existence of skill complementarities between workers trained in different countries. These synergies result in better labor market outcomes for natives, and in higher productivity in the R\&D sector. Our results are robust to the exclusion of some census years, to the set of US states included in the sample, to the measurement of diversity, and to the definition of a high-skilled immigrant. The results hold true when we eliminate states with the greatest or smallest levels of immigration share, states located on the Mexican border, and states with the lowest proportions of immigrants. They are also valid when we exclude undocumented immigrants and those who arrived in the US at a young age. In addition, we find no evidence of an inverted-U shaped relationship as found by Ashraf and Galor 2013) for genetic diversity, or of a negative epidemiological effect $a$ la Collier (2013) and Borjas 2015). The growth-enhancing effect of diversity is maximized when immigrants originate from economically or culturally distant countries (but not both), and when immigrants acquired primary and part of their secondary education abroad and their college education in the US.

To address endogeneity issues, we combine placebo tests with IV regressions. As far as the latter are 
concerned, we consider two instrumentation strategies that have been used in the related literature. The first one is a shift-share strategy a la Ottaviano and Peri (2006) which includes the predicted diversity indices based on total US immigration stocks by country of origin, and the bilateral state shares observed in 1960 . The second strategy consists in instrumenting diversity indices, using the immigration predictions of a pseudogravity regression that include interactions between year dummies and the geographic distance between each country of origin and each state of destination (in line with Feyrer (2019) or Alesina et al. (2016)). In both cases, diversity among college-educated migrants remains highly significant, while diversity among the less educated is insignificant or weakly significant. In the preferred specifications, the coefficient of high-skilled diversity remains around 0.6. Since the average diversity index among college-educated immigrants equaled 0.937 in 2010; hence, increasing diversity from zero to 0.937 increases GDP per capita by $58 \%$. However, in 2010, the high-skilled diversity indices of the US states ranged from 0.797 to 0.976. This implies that, if all US states had the same level of diversity as the District of Columbia (0.976), the average GDP per capita of the US would be $2.33 \%$ larger, the coefficient of variation across states would be $2.37 \%$ smaller, and the Theil index would decrease by 3.45\%. By comparison, if all US states had the same average level of human capital as the District of Columbia, the average GDP per capita of the US would be $8.32 \%$ larger, the coefficient of variation across states would be $9.77 \%$ smaller, and the Theil index would decrease by $16.06 \% 4$ Since the US-state average level of diversity among college-educated immigrants increased by 7 percentage points between 1960 and 2010; this explains a 3.5\% increase in macroeconomic performance (i.e. one fiftieth of the total change in the US level of GDP per capita).

The remainder of the paper is organized as follows. Section 2 describes our main diversity measures and documents the global trends in cultural diversity since WW2. Section 3 describes our empirical strategy. The results are discussed in Section 4 . Finally, Section 5 concludes.

\section{Birthplace diversity in the US states (1960-2010)}

Following Ottaviano and Peri (2006), Ager and Brückner (2013), Suedekum et al. (2014) and Alesina et al. (2016), we consider that the cultural identity of individuals is mainly determined by their country of birth. The rationale is that the competitiveness of modern-day economies is closely linked to the average level of the human capital of workers and to the complementarity between their skills. On the one hand, workers originating from different countries were trained in different school systems and are more likely to bring complementary skills, cognitive abilities and productive traits. On the other hand, the diversity of the labor force can induce communication and cooperation costs. Whether or not the gains exceed the costs is a key empirical question.

\footnotetext{
${ }^{4}$ The GDP per capita of Hawaii (diversity index of 0.797 ) would be $11.66 \%$ larger if Hawaii had the same diversity index as the District of Columbia; the difference in high-skilled diversity explains about $4.7 \%$ of the total income gap between Hawaii and the District of Columbia in 2010.
} 
In our empirical framework, our key explanatory variable is an index of birthplace diversity (or fractionalization), which can be computed for each US state and for the high-skilled and low-skilled populations separately. In subsection 2.1 we define various measures of birthplace diversity, establish links between them, and discuss their statistical correlation with the average immigration rate. In subsection 2.2, we then document the global US trends in cultural diversity observed since WW2.

\subsection{The Birthplace Diversity Index}

In line with existing studies, we first define a Herfindahl-Hirschmann index of birthplace diversity, a term which was first introduced by Alesina et al. (2016). This index is denoted by $T D_{s, t}^{K}$ and can be computed for the skill group $K=(L, H, A)$ ( $L$ for the low skilled, $H$ for the high skilled, and $A$ for both groups), for each state $s=(1, \ldots, S)$ and for each year $t=(1, \ldots, T)$. It measures the probability that two randomlydrawn individuals from the type- $K$ population of a particular state originate from two different countries of birth. As shown by Alesina et al. (2016) in a cross-country setting, the birthplace diversity index is poorly correlated with genetic, linguistic or ethnolinguistic fractionalization indices. The index is defined as:

$$
T D_{s, t}^{K}=\sum_{i=1}^{I} k_{i, s, t}^{K}\left(1-k_{i, s, t}^{K}\right)=1-\sum_{i=1}^{I}\left(k_{i, s, t}^{K}\right)^{2},
$$

where $k_{i, s, t}^{K}$ is the share of individuals of type $K$, born in country $i$, and living in state $s$, in the type- $K$ resident population of the state at year $t$. Computing the birthplace diversity index requires collecting panel data on the structure of the population by region of destination, by country of origin, and by education level. Our sample includes all US states (as well as the District of Columbia) between 1960 and 2010 in ten-year intervals, i.e. $s=(1, \ldots, 51)$ and $t=(1960, \ldots, 2010)$. Our choice to conduct the analysis at the state level is guided by the availability of long-term data series on macroeconomic performance, and by the comparability with cross-country results. We identify a common set of 195 countries of origin, including the US as a whole 5

Building on Alesina et al. (2016), the additive decomposition of the diversity index allows to distinguish between the Between and the Within components of the diversity index, $T D_{s, t}^{K}=B D_{s, t}^{K}+W D_{s, t}^{K}$. On the one hand, the Between component $B D_{s, t}^{K}$ measures the probability that a randomly-drawn pair of type- $K$ residents includes a native and an immigrant, irrespective of where the immigrant comes from 6

$$
B D_{s, t}^{K}=2 k_{U S, s, t}^{K}\left(1-k_{U S, s, t}^{K}\right)
$$

${ }^{5}$ With the the exception of section 4.3.1, we disregard heterogeneity between US natives born in different states (e.g. a Texan native is considered identical to a Californian one). See subsection 2.2 for a detailed description of the data. time $t$.

${ }^{6}$ In our specific case, $k_{U S, s, t}^{K}$ represents the share of US natives in the type- $K$ population of state $s$ at 
On the other hand, the residual Within component $W D_{s, t}^{K}$ measures the probability that a randomlydrawn pair of type- $K$ residents includes two immigrants born in two different countries:

$$
W D_{s, t}^{K}=\sum_{i \neq s}^{I} k_{i, s, t}^{K}\left(1-k_{i, s, t}^{K}-k_{U S, s, t}^{K}\right) .
$$

In the US context, the evolution of the birthplace diversity index among residents is almost totally driven by the change in the Between component of diversity, $B D_{s, t}^{K}$, which only depends on the proportion of immigrants. The median share of the Between component in total diversity, $B D_{s, t}^{A} / T D_{s, t}^{A}$, equals $98 \%$ and its quartiles are equal to $92 \%$ and $97 \%$. Similar findings are found for the low-skilled and high-skilled populations. Consequently, birthplace diversity in group $K$ is almost perfectly correlated with the statewide proportion of immigrants $7^{7}$ On average, the Pearson correlation between $T D_{s, t}^{K}$ and the total share of immigrants in the population, $m_{s, t}^{K}=\left(1-k_{U S, s, t}^{K}\right)$, equals 0.99 for all $K$. It is thus impossible to statistically disentangle the effects of diversity from those of the size of immigration. For this reason and in line with existing works, our empirical specification distinguishes between the size of immigration and the variety of immigrants.

To capture the variety effect, we start from the Within component of the diversity index. The Within component can be expressed as the product of the square of the immigration rate (the probability that two randomly-drawn individuals are immigrants) by an index of diversity among immigrants, $M D_{s, t}^{K}$. The latter measures the probability that two randomly-drawn immigrants from state $s$ originate from two different countries of birth. We have:

$$
\begin{aligned}
W D_{s, t}^{K} & =\left(1-k_{U S, s, t}^{K}\right)^{2} M D_{s, t}^{K} \\
& =\left(1-k_{U S, s, t}^{K}\right)^{2} \sum_{i \neq s} \widehat{k}_{i, s, t}^{K}\left(1-\widehat{k}_{i, s, t}^{K}\right),
\end{aligned}
$$

where $\widehat{k}_{i, s, t}^{K}=k_{i, s, t}^{K} /\left(1-k_{U S, s, t}^{K}\right)$ is the share of immigrants from origin country $i$ in the total immigrant population of state $s$. Contrary to the total index of diversity and to its Between and Within components, the correlation between $M D_{s, t}^{K}$ and the total immigration rate, $m_{s, t}^{K}$, is small (on average, -0.19). This allows us to simultaneously include these two variables in the same regression without fearing collinearity problems.

\subsection{Data and stylized facts}

Population data at the state level for the US are available from the Integrated Public Use Microdata Series (IPUMS). IPUMS data are drawn from the federal census of the American Community Surveys. For each census year, they allow to characterize the evolution of the American population by country of birth, by age, by level of education, and by year of arrival in the US, among others. We extract the data from 1960 to

${ }^{7}$ Table A4 in the Appendix provides correlations between diversity indices, and between diversity and the immigration rate. 
Figure 1: Trends in birthplace diversity in the US, 1960-2010

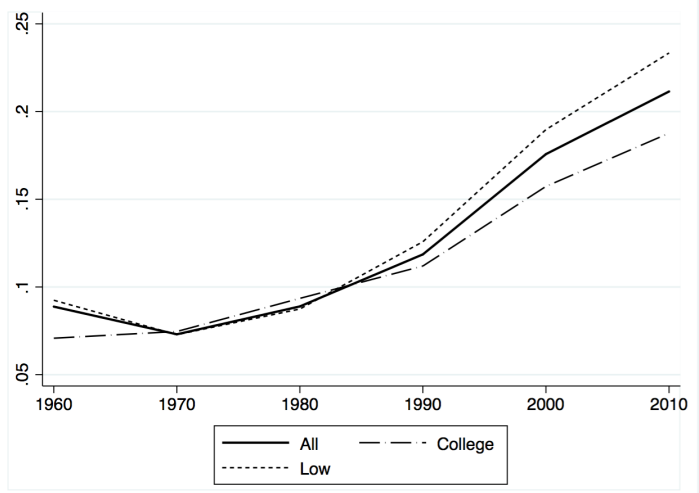

(a) Total diversity $\left(T D_{s, t}^{K}\right)$

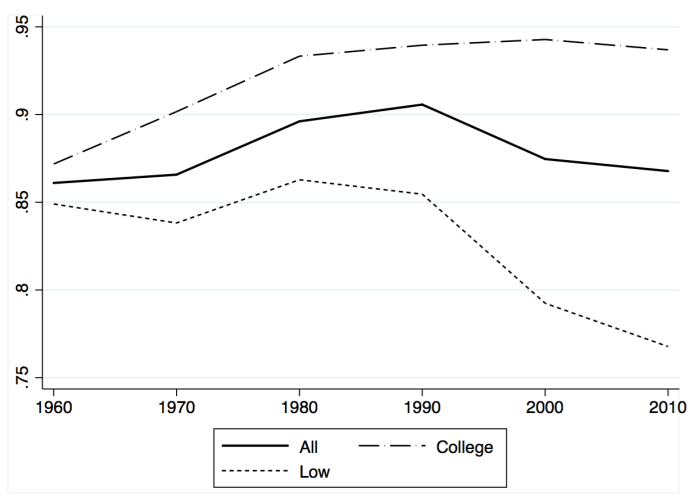

(b) Diversity among immigrants $\left(M D_{s, t}^{K}\right)$

Notes: Total diversity (among residents) is defined as in Eq. (1), whereas diversity among immigrants is defined as in Eq. (2). Source: Authors' elaboration on IPUMS data.

2010 in ten-year intervals, using the $1 \%$ census sample for the years 1960 and 1970 , the $5 \%$ census sample for the years 1980, 1990 and 2000, and the American Community Survey (ACS-1\%) sample for the year 2010. Regarding the origin countries of immigrants, we consider the full set of countries available in 2010, although some of them had no legal existence in the previous census years. Hence, for the years 1960 to 1990, data for the former USSR, former Yugoslavia and former Czechoslovakia are split using the country shares observed in the year 2000. In addition, we treat five pairs of countries as a single entity; this is the case of East and West Germany, Kosovo, Serbia and Montenegro, North and South Korea, North and South Yemen, and Sudan and South Sudan. Finally, we allocate individuals with a non-specified (or an imperfectly specified, respectively) country of birth proportionately to the country shares in the US population (or to the country shares in the US population originating from the reported region, respectively).

In our benchmark regressions, we restrict our micro sample to all individuals aged 16 to 64, who are likely to affect the macroeconomic performance of their state of residence. We distinguish between two skill groups. Individuals with at least one year of college are classified as highly skilled, whereas the rest of the population is considered as low skilled. We define as US natives all individuals born in the US or in US-dependent territories such as American Samoa, Guam, Puerto Rico, the US Virgin Islands and other US possessions. Foreign-born individuals are referred to as immigrants. Observations are aggregated at state level using IPUMS sample weights.

In alternative regressions, we only consider immigrants who arrived in the US after a certain age, or immigrants who are likely to have a legal status. As for the age-of-entry correction, we sequentially eliminate immigrants who arrived before the age of $5,6, \ldots, 25$. In order to proxy the number of undocumented immigrants, we follow the "residual methodology" described in Borjas (2017), and use information on the respondents' characteristics (such as citizenship, working sector, occupation, whether they receive public 
Figure 2: Cross-state differences in birthplace diversity, 1960-2010 average index

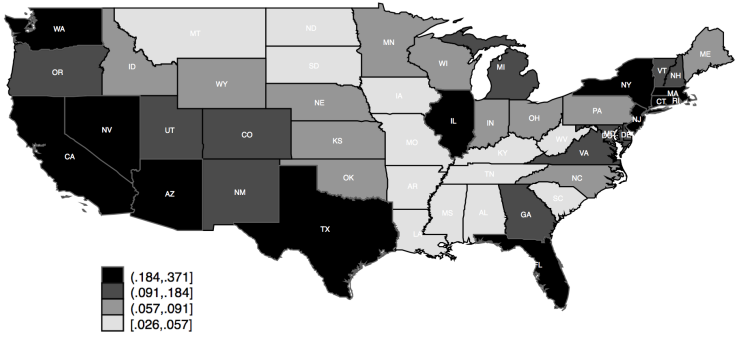

(a) Diversity among residents $\left(T D_{s, t}^{A}\right)$

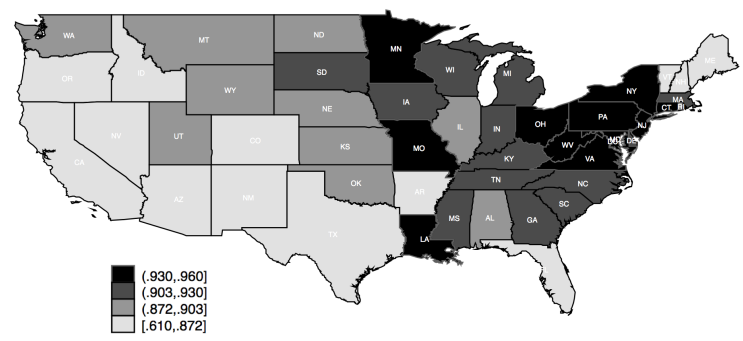

(b) Diversity among immigrants $\left(M D_{s, t}^{A}\right)$

Notes: Diversity among residents is defined as in Eq. (1), whereas diversity among immigrants is defined as in Eq. (2). The two maps present the average birthplace diversity observed between 1960 and 2010. Alaska and Hawaii are not represented. Source: Authors' elaboration on IPUMS data.

assistance, etc.).

We use IPUMS data to identify the bilateral stocks and shares of international migrants, $k_{i, s, t}^{K}$, in the population of each state $s$, by country of origin $i$ and by education level $K$ in year $t$. We thus construct comprehensive matrices of "Origin $\times$ State $\times$ Skill" stocks and shares from 1960 to 2010 in ten-year intervals $8^{8}$ Missing observations are considered as zeroes, even if a positive number of immigrants is identified for an adjacent year 9

The evolution of the average index of cultural diversity is described in Figure 11 whereas Figure 2 represents differences in the average level of diversity across US states. Figure 11(a) describes the evolution of the birthplace diversity index computed for the resident population, $T D_{s, t}^{K}$ for $K=(L, H, A)$, between 1960 and 2010. Looking at the average of all US states, the birthplace diversity index among residents increased from about 0.09 in 1960 to 0.21 in 2010, reflecting the general rise in immigration to the US. A large portion of this change occurred after 1990. Nevertheless, this average trend conceals significant differences between US states and between skill groups. As far as cross-state differences are concerned, the number of immigrants drastically increased in states such as California $(+195 \%)$ or New York $(+91 \%)$; on the contrary, the number of foreign-born individuals remained small and stable in other states such as Montana or Maine. Regarding differences between skill groups, changes in immigration rates were larger for the low skilled than for college graduates, particularly after the year 1980. This is mainly due to the large inflows of low-skilled Mexicans observed over the last three decades, which drastically affected the level of diversity in states located on the

\footnotetext{
${ }^{8}$ We distinguish between 195 countries of birth and 50 US states plus the District of Columbia. Countries and states are listed in Appendix A1. Descriptive statistics by state are provided in Table A3.

${ }^{9}$ We identify 33,145 origin-state dyads with zero migrants out of a sample of 59,670 observations (i.e. $55.5 \%$ of zeroes). The missing values are mostly concentrated in the years 1960 and 1970. Information on the country of origin is not reported for $0.3 \%$ of individuals at the micro level. We treat these observations as missing information when we aggregate our data by country of origin at state level.
} 
West Coast and along the US-Mexican border (see Figure 2|(a) below).

Second, Figure $1[(\mathrm{~b})$ describes the evolution of the diversity index computed for the immigrant population, $M D_{s, t}^{K}$ for $K=(L, H, A)$. It shows that the evolution of diversity in the immigrant population varies across skill groups. Diversity among college-educated immigrants has always been greater than diversity among the less educated. This might be due to the fact that college-educated migrants are less prone to concentrate in regions where large migration networks exist; they consider moving to more (geographically) diversified locations. Differences between skill groups drastically increased after 1960. On the one hand, diversity among high-skilled immigrants increased during the sixties and seventies, possibly due to the the Immigration and Nationality Act of 1965. Changes have been smaller since 1980 despite the Immigration Act of 1990, which allocated 50,000 additional visas (in the form of a lottery) to people from non-typical origin countries. On the other hand, diversity among low-skilled immigrants has fallen since 1980. Again, the latter decline is mainly explained by the large inflows of low-skilled Mexicans. Along the Mexican border and on the West Coast, the probability that two randomly-drawn immigrants were born in two different countries decreased as the share of Mexicans increased. This is also illustrated in Figure 2(b), which reveals significant cross-state differences in the average level of diversity among immigrants.

In sum, the evolution of diversity among immigrants varies across US states and over time. We show in the Appendix (see Figure A3) that diversity among immigrants decreased in states located along the USMexican border and on the West Coast. A rise in diversity was observed in other states (such as Maine or Vermont). Our panel data analysis takes advantage of these intra-state and inter-state variations to identify a causal effect of diversity on macroeconomic performance.

\section{Empirical Strategy}

Our goal is to assess the effect of birthplace diversity on the macroeconomic performance of US states ${ }^{10}$ The level of macroeconomic performance is measured by the log of the Gross Domestic Product (GDP) per capita. We present the benchmark specification in subsection 3.1. Subsection 3.2 explains how we deal with endogeneity issues, relying on placebo and IV regressions and combining two instrumentation strategies.

\subsection{Benchmark Specification}

Our benchmark empirical model features the log of GDP per capita as the dependent variable. In line with Ottaviano and Peri (2006), Ager and Brückner (2013), Suedekum et al. (2014) and Alesina et al. (2016), we

\footnotetext{
${ }^{10}$ In the Appendix, a complementary analysis is conducted on the 34 OECD member states, using population data from Özden et al. (2011). The first drawback of the database is that it does not report the educational structure of migration stocks. To capture skill-specific effects, we combine it with the 1990-2000 estimates of the bilateral proportion of college graduates provided in Artuc et al. (2015). The second drawback is that it relies on imputation techniques to fill the missing bilateral cells. Despite the lower quality of the data, our fixed-effect analysis globally confirms the results obtained for US states.
} 
use the following specification:

$$
\log \left(y_{s, t}\right)=\beta_{1} M D_{s, t}^{K}+\beta_{2} m_{s, t}^{K}+\boldsymbol{\lambda}^{\prime} \boldsymbol{X}_{s, t}+\gamma_{s}+\gamma_{t}+\varepsilon_{s, t},
$$

where $\log \left(y_{s, t}\right)$ is the $\log$ of GDP per capita in state $s$ at year $t, M D_{s, t}^{K}$ is the type- $K$ birthplace diversity among immigrants (proxy for the variety of immigrants), and $m_{s, t}^{K}$ is the proportion of immigrants in the working-age population of type $K$. The latter is a key control variable that potentially captures the other channels through which the level of immigration affects macroeconomic performance (e.g. labor market, fiscal or market-size effects). We opt for a static specification and assume that changes in diversity fully materialize within 10 years. This spares us from dealing with the endogeneity of the lagged dependent, an important issue in dynamic models with a short-panel dimension (Nickel, 1981) ${ }^{11}$ Coefficient $\beta_{1}$ is our coefficient of interest. It captures the effect of birthplace diversity on macroeconomic performance.

Using skill-specific measures of cultural diversity and immigration, $K=(L, H, A)$, we can identify whether the level and significance of $\beta_{1}$ vary across skill groups. One might be concerned that using skillspecific regressions leads to an omitted variable bias. This can be the case if the origin mixes of high-skilled and low-skilled immigrants (and the skill-specific diversity indices) are correlated across states. However, the main reason for using skill-specific regressions is that the correlation between $m_{s, t}^{H}$ and $m_{s, t}^{L}$ exceeds 0.9 . Hence, we estimate $\beta_{1}$ separately to avoid collinearity issues. Nonetheless, unreported regressions (available upon request) show that our results for diversity hold when including the two variables jointly.

We first estimate Eq. (3) using pooled OLS regressions, bearing in mind that such regressions raise a number of econometric issues that might generate inconsistent estimates. The key issue when using pooled OLS regressions is the endogeneity of the main variable of interest, the index of diversity. Endogeneity can be due to a number of reasons. These reasons include the existence of uncontrolled confounding variables causing both dependent and independent variables, the existence of a two-way causal relationship between these variables, or a measurement problem. To mitigate the possibility of an omitted variable bias, our specification includes a full set of state and year fixed effects, $\gamma_{s}$ and $\gamma_{t}$, which allows us to partly account for unobserved heterogeneity (including initial conditions in 1960). In addition, our benchmark model includes a vector $\boldsymbol{X}_{s, t}$ of time-varying covariates through which immigration is likely to affect the level of macroeconomic performance. It includes the log of population, the log of the state-wide average educational attainment of the working-age population (as measured by the years of schooling or highest degree completed), and the $\log$ of the urbanization rate. As highlighted in Angrist and Pischke (2009), these control variables can be suspected of acting as "bad controls" if they are determined simultaneously with the level of diversity. For this reason, we provide supplementary OLS and FE regressions without control variables in section 4.1. They

\footnotetext{
${ }^{11}$ Nevertheless, Tables F1 and F2 in the Appendix provide the results of dynamic GMM regressions with internal or external instruments, and with different lag structures. In these regressions, the lagged dependent is insignificant or weakly significant, which reinforces the credibility of our static benchmark specification. In addition, the effects of diversity are qualitatively similar to those obtained in the static model.
} 
show that our results are highly robust to the inclusion or the exclusion of these controls ${ }^{12}$ Finally, to solve the reverse causation and measurement problems, we use placebo tests and two methods of instrumental variables described in subsection 3.2

Finally, our benchmark specification in Eq. (3) assumes linear effects of the level of immigration and of the variety of immigrants on the log of GDP per capita. However, the literature on diversity suggests that the technology of transmission of cultural shocks can be different. In particular, another strand of the literature focuses on migration-induced transfers of norms, and tests for potential epidemiological or contamination effects. Transfers of norms from origin to destination countries have been examined by a limited set of studies 13 Comparing the economic performance of US counties from 1850 to 2010, Fulford et al. (2017) show that the country-of-ancestry distribution of the population matters, and that the estimated effect of ancestry is governed by the sending country's level of economic development, as well as by measures of social capital at origin (such as trust and thrift). Putterman and Weil (2010) study the effect of ancestry in a cross-country setting, and find that the ancestry effect is governed by a measure of state centralization in 1500. More recently, debates about the societal implications of diversity have been revived in the migration literature. Collier (2013) and Borjas (2015) emphasize the social and cultural challenges that movements of people may induce.

The birthplace diversity index used in the benchmark specification neither accounts for characteristics of the origin countries not for the distance with the state of destination. Two strategies are used to account for origin-specific characteristics and potential epidemiological effects. The first consists in supplementing our specification with $M Y_{s, t}^{K}$, the weighted average of the log of GDP per capita in the origin countries of type- $K$ immigrants to state $s$ (the weights are equal to the bilateral shares of immigrants). The epidemiological term is defined as:

$$
M Y_{s, t}^{K}=\sum_{i \neq s}^{I} \widehat{k}_{i, s, t}^{K} \log \left(y_{i, t}\right) .
$$

On average, the correlation between this term and the diversity index is small (around -0.17 across US states), so that both variables can be tested jointly. Similarly, the correlation with the immigration rate is small as well $(-0.26){ }^{14}$

${ }^{12}$ Table $\mathrm{B10}$ in the Appendix reports the results of IV regressions without controls. Remember that we also provide System-GMM regressions in Table F1 and F2 that correct for the endogeneity of each covariate using its own lags as instruments. These robustness checks confirm the results of our benchmark regressions.

${ }^{13}$ More studies focus on emigration-driven contagion effects, i.e. the effects of migrants' destinationcountry characteristics on outcomes at origin. The most popular study is that of Spilimbergo (2009), which investigates the effect of foreign education on democracy. Beine et al. (2013) and Bertoli and Marchetta (2015) use a similar specification to examine the effect of emigration on source-country fertility. Lodigiani and Salomone (2012) find that emigration to countries with greater female participation in parliament increases female participation in the origin country. More recently, Docquier et al. (2016) and Barsbai et al. (2017) find that emigration to democratic countries has a positive effect on the quality of institutions in developing countries.

${ }^{14}$ Alesina et al. (2016) control for such epidemiological terms and find insignificant effects. Compared 
The second strategy consists in replacing $M D_{s, t}^{K}$ by an augmented Greenberg index (Greenberg, 1956) that accounts for the economic and cultural distances between the origin country and the US. By varying the parameters of the augmented index, we can uncover the conditions under which the beneficial or detrimental effects of diversity are maximized. In line with Alesina et al. (2016), our Greenberg diversity index is written:

$$
M D_{s, t}^{K, A u g}=\sum_{i \neq s} \widehat{k}_{i, s, t}^{K}\left(1-\widehat{k}_{i, s, t}^{S}\right) \times d_{U S, i} \times e_{i, t}
$$

The Greenberg index combines two measures of distance, $d_{U S, i}$ and $e_{i, t}$ normalized between 0 and 1 . For each distance we use a standard logistic function allowing us to weight these distances by factors $\theta_{1}$ and $\theta_{2}$ that vary between -10 and +10 . The first distance $\left(d_{U S, i}\right)$ is the cultural distance between origin country $i$ and the US:

$$
d_{U S, i}=2 /\left(1+e^{-\left(\theta_{1} * D_{U S, i}^{d}\right)}\right)
$$

For $D_{U S, i}^{d}$, we alternatively use time-invariant measures of linguistic and genetic distance. Data on linguistic distance are taken from Head et al. $(2010) . D_{U S, i}^{d}$ is a dummy equal to one if a language is spoken by at least $9 \%$ of the population in both countries. Data on genetic distance are taken from Spolaore and Wacziarg (2009) 15

The second distance $\left(e_{i, t}\right)$ is a measure of economic distance between the origin country and the US:

$$
e_{i, t}=2 /\left(1+e^{-\left(\theta_{2} * D_{i, t}^{e}\right)}\right)
$$

Variable $D_{i, t}^{e}$ is proxied by the level of GDP per capita in the origin country only, to avoid using our dependent variable on the right-hand side of the regression equation. The use of panel data allows us to compute our Greenberg index with a time-varying measure of economic distance.

When both weights $\left(\theta_{1}\right.$ and $\left.\theta_{2}\right)$ are equal to zero, our augmented index is equivalent to the standard Herfindahl index. However, when $\theta_{1}$ increases (for a given $\theta_{2}$ ), our Greenberg index over-weights immigrants from culturally distant countries. Similarly, when $\theta_{2}$ increases (for a given $\theta_{1}$ ), our Greenberg index overweights immigrants from richer countries, i.e. from less economically distant countries.

to them, we consider several variants of Eq. (4) in the Appendix, and we also instrument epidemiological terms.

${ }^{15}$ Due to missing values, we eliminate 12 countries from our sample of 195 origins (Andorra, Bosnia, East Timor, Holy See, Liechtenstein, Marshall Islands, Micronesia, Monaco, Nauru, Occupied Palestinian Territories and Tuvalu). In 2010, these countries accounted for $0.3 \%$ of the high-skilled immigrant stock in the US. 


\section{$3.2 \quad$ Identification Strategy}

Although our benchmark specification includes time-varying covariates and a full set of fixed effects, the association between birthplace diversity and macroeconomic performance can still be driven by reverse causality. As argued by Alesina and La Ferrara (2005), diversity is likely to respond to changes in the economic environment. The sign of the bias is ambiguous, especially when working at the state level. On the one hand, an upward bias can be observed if more rapidly growing states attract more immigrants from more diverse countries (e.g. due to higher income levels and business diversification). On the other hand, a downward bias can be observed if more rapidly growing states attract more immigrants from a limited set of origin countries (e.g. due to border and/or network effects). The example of states located on the Mexican border is highly relevant in this context (see Figures $2(\mathrm{a})$ and $2(\mathrm{~b})$ ).

Therefore, we use two strategies for dealing with reverse causation issues. As a placebo regression, we first augment our benchmark specification with natives' migration rates (denoted by $n_{s, t}^{K}$ ), and measures of diversity computed for the native population (denoted by $N D_{s, t}^{K}$ ). More precisely, we use the IPUMS data to identify the state of birth and the state of residence of each American citizen, and we compute internal migration rates and indices of diversity by state of birth for both skill groups. The latter index measures the probability that two randomly-drawn Americans from the type- $K$ population of a particular state originate from two different states of birth. If diversity responds to economic prosperity, we expect a positive correlation between $N D_{s, t}^{K}$ and GDP per capita.

Secondly, we use two-stage least-square estimation methods. We consider two different sets of instruments that have been used in the existing literature, and show that our IV results are robust to the instrumentation strategy. Our first IV strategy is a shift-share strategy a la Ottaviano and Peri (2006) or Ager and Brückner (2013). We instrument diversity with predicted indices combining the changes in US immigration stocks by country of origin and the dyadic shares observed in 1960. More precisely, we predict the skill-specific bilateral migration stocks for each state using the residence shares of natives and immigrants observed in 1960. Then, we use these shares to allocate new immigrants by state of destination. The predicted stock of migrants at time $t$ is:

$$
\widehat{\text { Stock }}_{i, s, t}^{K}=\text { Stock }_{i, s, 1960}^{K}+\phi_{i, s}^{K}\left(\text { Stock }_{i, t}^{K}-\text { Stock }_{i, 1960}^{K}\right),
$$

where $S t o c k_{i, s, t}^{K}$ is the type- $K$ stock of immigrants from country $i$ residing in state $s$ at year $t$. Term $\phi_{i, s}^{K}$ is the time-invariant share that we use to allocate the variation in the bilateral migration stocks observed between the years 1960 and $t$. We thus allocate changes in bilateral migration stocks using the 1960 skill-specific shares of US natives and immigrants from the same origin country. These shares capture both origin- and skill-specific network effects, and the concentration of type- $K$ workers in 1960 . We have:

$$
\phi_{i, s}^{K}=\left(N a t_{s, 1960}^{K}+S t o c k_{i, s, 1960}^{K}\right) /\left(\sum_{s}\left(N a t_{s, 1960}^{K}+\text { Stock }_{i, s, 1960}^{K}\right)\right)
$$


where $N a t_{s, 1960}^{K}$ is the number of US natives residing in state $s$ at year 1960. Using the predicted stock of migrants (who are less likely to be affected by the economic performance of each state), we compute the predicted diversity indices.

In line with Feyrer (2019) or Alesina et al. (2016), our second IV strategy consists in instrumenting diversity indices using the predicted migration stocks obtained from a "zero-stage," pseudo-gravity regression. The latter regression includes interactions between year dummies and the geographic distance between each country of origin and each US state. In line with the shift-share strategy, the identification thus comes from the time-varying effect of geographic distance on migration, reflecting gradual changes in transportation and communication costs. The pseudo-gravity model is written:

$$
\log \left(\operatorname{Stock}_{i, s, t}^{K}\right)=\beta_{t} \log \left(\text { Dist }_{i, s}\right)+\text { Bord }_{i, s}+\operatorname{Lang}_{i, s}+\gamma_{s}+\gamma_{i}+\gamma_{t}+\varepsilon_{i, s, t},
$$

where $\operatorname{Bord}_{i, s}$ is a dummy equal to one if country $i$ and state $s$ share a common border, $\operatorname{Lang}_{i, s}$ is a dummy equal to one if at least $9 \%$ of the populations of $i$ and $s$ speak a common language, $\gamma_{s}, \gamma_{i}$, and $\gamma_{t}$ are the destination, origin and year fixed effects ${ }^{16}$ In the pseudo-gravity stage, the high prevalence of zero values in bilateral migration stocks gives rise to econometric concerns about possible inconsistent OLS estimates. To address this problem, we use the Poisson regression by pseudo-maximum likelihood (see Santos Silva and Tenreyro, 2006). Standard errors are robust and clustered by country-state pairs.

Although commonly used in the literature, each of these IV strategies has some drawbacks. We are aware that the shift-share method is imperfect if potential regressors exhibit strong persistence, and that the relative geography variables used in the strategy a la Feyrer (2019) can affect macroeconomic performance through other channels such as trade, foreign direct investments or technology diffusion (not measurable at the state level for the 1960-2010 period). Nevertheless, we can reasonably support a careful causal interpretation of our results if these strategies and the placebo regressions yield consistent and converging results.

\section{Results}

Our empirical analysis follows the structure described in section 3 . In subsection 4.1, we investigate the effect of birthplace diversity among immigrants using pooled OLS regressions; we produce separate results for the total immigrant population and for the two skill groups. Then, we test for the existence of epidemiological effects, and we control for unobserved heterogeneity, including a full set of state and year fixed effects (FE). In subsection 4.2, we show that the FE estimates are highly robust to different robustness checks and subsamples. In subsection 4.3 , we deal with endogeneity issues, discussing the results of placebo and IV regressions. The latter rely on two instrumentation strategies frequently used in the existing literature (i.e a

\footnotetext{
${ }^{16}$ One could be concerned that the border dummies in the pseudo-gravity equation impose a very strong functional form input on the instrumental variables estimates. However, it is worth noting that removing these two variables from our equation does not change significantly our main coefficients of interests.
} 
shift-share strategy a la Ottaviano and Peri (2006) and a gravity-like strategy a la Feyrer (2019)). Finally, in subsection 4.4 , we extend the IV setting and conduct an exploratory analysis of the channels of transmission through which birthplace diversity affects economic growth.

\subsection{Pooled OLS and FE Regressions}

Table 1 describes the pooled OLS and FE estimates without and with covariates in Tables 1(a) and 1(b), respectively. We produce separate results for the three skill groups, $K=(A, L, H)$, under the same set of potential confounding factors. These include the skill-specific immigration rate, $m_{s, t}^{K}$, the log of population, $\log \left(P o p_{s, t}\right)$, the $\log$ of urbanization, $\log \left(U r b_{s, t}\right)$, and the $\log$ of the average educational attainment of the working-age population, $\log \left(H u m_{s, t}\right)$. In all cases, our standard errors are clustered at the state level in order to correct for heteroskedasticity and serial correlation.

The pooled OLS estimates are reported in col. 1, 3 and 6. The effect of birthplace diversity on GDP per capita is skill-specific. Insignificant effects are obtained when diversity is computed using the low-skilled immigrant population. On the contrary, the association between GDP per capita and high-skilled diversity is positive and significant at the $1 \%$ level. The coefficient is large: a $10 \%$ increase in high-skilled diversity is associated with a $27.2 \%$ increase in GDP per capita when potential confounding factors are accounted for, and even more without controls. When computing the diversity index on the total immigrant population, the effect remains significant at the $1 \%$ level in the regression without controls, but it becomes insignificant when the covariates are included.

Col. 2, 4 and 7 describe the (benchmark) results obtained when we add state and year fixed effects. The state fixed effects account for all time-invariant state characteristics that could jointly affect productivity and diversity; the year fixed effects account for time-varying sources of change in GDP per capita that are common to all US states ${ }^{17}$ In the FE regressions, the R-squared is above 0.99. The effect of high-skilled diversity remains highly significant. Interestingly, the inclusion of fixed effects leads to a drop in the coefficient of interest. It is divided by four compared to the pooled OLS regression. This demonstrates that accounting for unobserved heterogeneity is crucial in this literature. As far as low-skilled diversity is concerned, the effect becomes significant in the regression without controls, but loses significance once covariates are factored in. Turning our attention to the potential confounding factors, human capital and urbanization rates are significantly and positively associated with GDP per capita. On the contrary, the correlation between GDP and population size is negative. More interestingly, immigration rates are always positively associated with GDP per capita, and the correlation is always greater for college graduates.

In col. 5 and 8, we supplement the benchmark model with epidemiological effects a la Collier (2013) and Borjas (2015). Interpreting the coefficient of the epidemiological term is not straightforward. On the one hand, if immigrants originating from poor countries contaminate the total factor productivity or the

\footnotetext{
${ }^{17}$ In order to better deal with unobserved heterogeneity, additional regressions with region-by-year fixed effects are provided in the Appendix. As shown in Table B12, our findings are not altered.
} 
Table 1: Pooled OLS and FE regressions

Results by skill group $\left(\mathrm{Dep}=\log \left(y_{s, t}\right)\right)$

\begin{tabular}{|c|c|c|c|c|c|c|c|c|}
\hline Skill level & $\begin{array}{l}(1) \\
\text { OLS } \\
\text { All }\end{array}$ & $\begin{array}{l}(2) \\
\text { FE } \\
\text { All }\end{array}$ & $\begin{array}{c}(3) \\
\text { OLS } \\
\text { Low skilled }\end{array}$ & $\begin{array}{c}(4) \\
\text { FE } \\
\text { Low skilled }\end{array}$ & $\begin{array}{c}(5) \\
\text { FE } \\
\text { Low skilled }\end{array}$ & $\begin{array}{c}(6) \\
\text { OLS } \\
\text { High skilled }\end{array}$ & $\begin{array}{c}\quad(7) \\
\text { FE } \\
\text { High skilled }\end{array}$ & $\begin{array}{c}(8) \\
\text { FE } \\
\text { High skilled }\end{array}$ \\
\hline \multicolumn{9}{|c|}{ Table1 a): Without control variables } \\
\hline Mig Div $v_{s, t}$ & $\begin{array}{c}2.084^{* * *} \\
(0.581)\end{array}$ & $\begin{array}{c}0.275^{* * *} \\
(0.097)\end{array}$ & $\begin{array}{c}0.343 \\
(0.498)\end{array}$ & $\begin{array}{c}0.147^{* *} \\
(0.063)\end{array}$ & $\begin{array}{c}0.096 \\
(0.060)\end{array}$ & $\begin{array}{c}7.595^{* * *} \\
(0.909)\end{array}$ & $\begin{array}{c}0.664^{* * *} \\
(0.209)\end{array}$ & $\begin{array}{c}0.556^{* * *} \\
(0.182)\end{array}$ \\
\hline Mig Share $_{s, t}$ & $\begin{array}{c}8.905^{* * *} \\
(1.267)\end{array}$ & $\begin{array}{l}-0.115 \\
(0.402)\end{array}$ & $\begin{array}{c}6.963^{* * *} \\
(1.053)\end{array}$ & $\begin{array}{l}-0.123 \\
(0.314)\end{array}$ & $\begin{array}{l}-0.152 \\
(0.315)\end{array}$ & $\begin{array}{c}9.912^{* * *} \\
(1.421)\end{array}$ & $\begin{array}{c}-0.019 \\
(0.452)\end{array}$ & $\begin{array}{l}-0.265 \\
(0.452)\end{array}$ \\
\hline$M Y_{s, t}$ & & & & & $\begin{array}{c}-0.150^{* * *} \\
(0.048)\end{array}$ & & & $\begin{array}{c}-0.174^{* *} \\
(0.068)\end{array}$ \\
\hline Constant & $\begin{array}{c}7.099 * * * \\
(0.523)\end{array}$ & $\begin{array}{c}7.847^{* * *} \\
(0.087)\end{array}$ & $\begin{array}{c}8.738^{* * *} \\
(0.436)\end{array}$ & $\begin{array}{c}7.960^{* * *} \\
(0.059)\end{array}$ & $\begin{array}{c}9.285^{* * *} \\
(0.419)\end{array}$ & $\begin{array}{c}1.931^{* *} \\
(0.861)\end{array}$ & $\begin{array}{c}7.501^{* * *} \\
(0.187)\end{array}$ & $\begin{array}{c}9.095^{* * *} \\
(0.614)\end{array}$ \\
\hline R-squared & 0.283 & 0.991 & 0.236 & 0.991 & 0.992 & 0.452 & 0.992 & 0.992 \\
\hline \multicolumn{9}{|c|}{ Table 1 b): With control variables } \\
\hline Mig Div ${ }_{s, t}$ & $\begin{array}{c}0.416 \\
(0.329)\end{array}$ & $\begin{array}{c}0.318^{* * *} \\
(0.114)\end{array}$ & $\begin{array}{c}0.019 \\
(0.184)\end{array}$ & $\begin{array}{c}0.141 \\
(0.086)\end{array}$ & $\begin{array}{c}0.104 \\
(0.085)\end{array}$ & $\begin{array}{c}2.719^{* * *} * \\
(0.719)\end{array}$ & $\begin{array}{c}0.616^{* * *} \\
(0.160)\end{array}$ & $\begin{array}{c}0.531^{* * *} \\
(0.159)\end{array}$ \\
\hline Mig Share S,t & $\begin{array}{c}2.632^{* * *} \\
(0.615)\end{array}$ & $\begin{array}{l}0.582^{*} \\
(0.341)\end{array}$ & $\begin{array}{c}1.901^{* * *} \\
(0.485)\end{array}$ & $\begin{array}{l}0.481^{*} \\
(0.282)\end{array}$ & $\begin{array}{c}0.412 \\
(0.283)\end{array}$ & $\begin{array}{c}4.383^{* * *} * \\
(1.018)\end{array}$ & $\begin{array}{l}0.614^{*} \\
(0.315)\end{array}$ & $\begin{array}{c}0.388 \\
(0.366)\end{array}$ \\
\hline$M Y_{s, t}$ & & & & & $\begin{array}{c}-0.104^{* *} \\
(0.042)\end{array}$ & & & $\begin{array}{l}-0.133^{*} \\
(0.069)\end{array}$ \\
\hline $\log \left(P_{o p}, t\right)$ & $\begin{array}{c}0.070 \\
(0.047)\end{array}$ & $\begin{array}{c}-0.172^{* *} \\
(0.079)\end{array}$ & $\begin{array}{l}0.079^{*} \\
(0.047)\end{array}$ & $\begin{array}{c}-0.166^{* *} \\
(0.081)\end{array}$ & $\begin{array}{c}-0.146^{*} \\
(0.082)\end{array}$ & $\begin{array}{c}0.011 \\
(0.044)\end{array}$ & $\begin{array}{c}-0.155^{* *} \\
(0.075)\end{array}$ & $\begin{array}{l}-0.080 \\
(0.065)\end{array}$ \\
\hline $\log \left(U r b_{s, t}\right)$ & $\begin{array}{c}-0.407^{*} \\
(0.238)\end{array}$ & $\begin{array}{c}0.385^{* *} \\
(0.156)\end{array}$ & $\begin{array}{l}-0.367 \\
(0.254)\end{array}$ & $\begin{array}{c}0.329^{* *} \\
(0.163)\end{array}$ & $\begin{array}{l}0.312^{*} \\
(0.173)\end{array}$ & $\begin{array}{c}-0.563^{* *} \\
(0.229)\end{array}$ & $\begin{array}{c}0.285^{* *} \\
(0.135)\end{array}$ & $\begin{array}{c}0.156 \\
(0.138)\end{array}$ \\
\hline $\log \left(H u m_{s, t}\right)$ & $\begin{array}{c}5.752^{* * *} \\
(0.157)\end{array}$ & $\begin{array}{c}0.695^{* * *} \\
(0.197)\end{array}$ & $\begin{array}{c}5.817^{* * *} \\
(0.147)\end{array}$ & $\begin{array}{c}0.807^{* * *} \\
(0.205)\end{array}$ & $\begin{array}{c}0.802^{* * *} \\
(0.196)\end{array}$ & $\begin{array}{c}5.288^{* * *} * \\
(0.182)\end{array}$ & $\begin{array}{c}0.759 * * * \\
(0.197)\end{array}$ & $\begin{array}{c}1.007^{* * *} \\
(0.299)\end{array}$ \\
\hline Constant & $\begin{array}{c}-0.697 \\
(0.890)\end{array}$ & $\begin{array}{c}7.529^{* * *} \\
(1.254)\end{array}$ & $\begin{array}{l}-0.728 \\
(0.914)\end{array}$ & $\begin{array}{c}7.662^{* * *} \\
(1.263)\end{array}$ & $\begin{array}{c}8.379^{* * *} \\
(1.317)\end{array}$ & $\begin{array}{l}-0.584 \\
(0.890)\end{array}$ & $\begin{array}{c}7.348^{* * *} \\
(1.262)\end{array}$ & $\begin{array}{c}7.492^{* * *} \\
(1.273)\end{array}$ \\
\hline R-squared & 0.879 & 0.993 & 0.878 & 0.993 & 0.993 & 0.889 & 0.993 & 0.993 \\
\hline Observations & 306 & 306 & 306 & 306 & 306 & 306 & 306 & 306 \\
\hline Nb. states & 51 & 51 & 51 & 51 & 51 & 51 & 51 & 51 \\
\hline Time fixed effects & No & Yes & No & Yes & Yes & No & Yes & Yes \\
\hline States fixed effects & No & Yes & No & Yes & Yes & No & Yes & Yes \\
\hline \multicolumn{9}{|c|}{$\begin{array}{l}\text { Notes: }{ }^{* * *} \mathrm{p}<0.01,{ }^{* *} \mathrm{p}<0.05,{ }^{*} \mathrm{p}<0.1 \text {. Standard errors in parentheses are clustered at the state level. The specification } \\
\text { is described in Eq. 3. Pooled OLS results are provided in col. } 1,3 \text { and } 6 ; \mathrm{FE} \text { results are provided in col. } 2,4,5,7 \text { and } \\
\text { 8. Results for all immigrants are provided in col. } 1 \text { and } 2 ; \text { results for low-skilled immigrants are provided in col. } 3,4 \text { and } \\
\text { 5; results for college-educated immigrants are provided in col. 6, } 7 \text { and } 8 \text {. The sample includes the } 50 \text { US states and the } \\
\text { District of Columbia from } 1960 \text { to } 2010 \text {. The set of control variables includes the immigration rate }\left(\text { Mig Share }_{s, t}\right) \text {, the log } \\
\text { of population }\left(\log \left(\operatorname{Pop}_{s, t}\right)\right) \text {, the } \log \text { of urbanization }\left(\log \left(U r b_{s, t}\right)\right) \text { and the } \log \text { of the average educational attainment of the } \\
\text { working-age population }\left(\log \left(\operatorname{Hum}_{s, t}\right)\right) \text {. We supplement our benchmark specification in col. } 5 \text { and } 8 \text { with the epidemiological } \\
\text { effect }\left(M Y_{s, t}\right) \text {. }\end{array}$} \\
\hline
\end{tabular}

quality of institutions at destination, we should find a positive and significant relationship between our epidemiological term $\left(M Y_{s, t}^{K}\right)$ and macroeconomic performance. On the other hand, if attracting immigrants from economically or culturally distant countries generates more complementarities in skills and ideas than immigrants from richer countries, we should find a negative and significant relationship. Overall, controlling for epidemiological terms does not affect our findings. The effect of low-skilled diversity remains insignificant in col. 5, and the effect of high-skilled diversity remains highly significant in col. 8. These results are robust to the specification of the epidemiological terms ${ }^{18}$ In addition, it is worth noticing that we find no evidence

\footnotetext{
${ }^{18}$ We consider alternative specifications for the epidemiological term in Appendix Table C1. We first
} 
of contamination effects after controlling for potential confounding factors. In col. 8, the coefficient of the epidemiological terms is weakly significant and negative. In col. 5 , the coefficient is negative and significant at the $5 \%$ level. Such a negative effect suggests that low-skilled immigrants from richer countries may generate fewer complementarities with the native workforce compared to immigrants from poorer countries. However, reverse causality is a source of concern here since economic growth is likely to affect the attractiveness of a state and the variety of its immigrant population. Our database reveals that richer states attract more people, including immigrants from poorer countries. This selection issue pushes the correlation between GDP per capita and the epidemiological term downwards 19 Such reverse causation issues are addressed in subsection 4.3 .

In sum, we find that diversity is positively associated with the level of GDP per capita, but only when diversity is computed on workers performing complex or skill-intensive tasks. On the contrary, diversity among less educated immigrants does not have a significant effect on macroeconomic performance. According to our fixed-effect estimates, a 10\% increase in high-skilled diversity (i.e. in the probability that two randomlydrawn, college-educated immigrants originate from two different countries of birth) is now associated with a $6.2 \%$ increase in GDP per capita. Expressed differently, a one-standard-deviation increase in high-skilled diversity is associated with a $3.2 \%$ increase in GDP per capita. This implies that, if all US states had the same level of diversity as the most diverse state in 2010, i.e. the District of Columbia (0.976), the average GDP per capita of the US would be $2.33 \%$ larger, the coefficient of variation across states would be $2.37 \%$ smaller, and the Theil index would decrease by $3.45 \%$. By comparison, if all US states had the same average level of human capital as the District of Columbia, the average GDP per capita of the US would be $8.32 \%$ larger, the coefficient of variation across states would be $9.77 \%$ smaller, the Theil index would decrease by $16.06 \%$ and the GDP per capita of Hawaii, the least diverse state in 2010 (0.797), would be $11.7 \%$ larger. In addition, the US-state average level of diversity among college-educated migrants increased by 7 percentage points between 1960 and 2010; this explains a 3.5\% increase in macroeconomic performance (i.e. only one fiftieth of the total change in the US level of GDP per capita).

compute $M Y_{s, t}^{K}$ by keeping the immigration shares $\left(\widehat{k}_{i, s, t}^{K}\right)$ constant, at their 1960-2010 average levels. Then, we keep the levels of GDP per capita at origin $\left(\log \left(y_{i, t}\right)\right)$ constant, at their 1960-2010 average level. Finally, we combine annual data on GDP per capita at origin with individual data on the year of arrival in the US; each immigration share is multiplied by the average level of GDP per capita prevailing in the year of immigration to the US. The latter specification allows us to capture the norms and values that immigrants bring with them when they migrate. Due to data limitations, this variable cannot be computed for the year 1960. Finally, we obtain the same conclusion when the epidemiological term in Eq. (4) is based on democracy levels at origin, instead of GDP per capita. We use the Polity2 index of democracy. The results for democracy are available upon request.

${ }^{19}$ Figure C1 in the Appendix confirms this presumption. When we keep the levels of GDP per capita constant for all origin countries (at their 1960-2010 average), we observe that the US state level of GDP per capita is negatively correlated with the epidemiological term. 
Table 2: Robustness of FE regressions for high-skilled diversity $\left(\operatorname{Dep}=\log \left(y_{s, t}\right)\right)$

\begin{tabular}{|c|c|c|c|c|c|c|c|}
\hline & \multicolumn{6}{|c|}{ Sub-sample B2 } & \multirow{2}{*}{$\begin{array}{c}\mathrm{CZ} \text { B4 } \\
(7) \\
C Z\end{array}$} \\
\hline & $\begin{array}{c}(1) \\
\text { Full-Sample }\end{array}$ & $\begin{array}{c}(2) \\
1970-2000\end{array}$ & $\begin{array}{c}(3) \\
\text { No Top5 }\end{array}$ & $\begin{array}{c}(4) \\
\text { No Bot5 }\end{array}$ & $\begin{array}{c}(5) \\
\text { No Mex }\end{array}$ & $\begin{array}{c}(6) \\
\text { No Q1 }\end{array}$ & \\
\hline Mig Div Ditt & $\begin{array}{c}0.616^{* * *} \\
(0.160)\end{array}$ & $\begin{array}{c}0.870^{* * *} \\
(0.321)\end{array}$ & $\begin{array}{c}0.725^{* * *} \\
(0.174)\end{array}$ & $\begin{array}{c}0.672^{* * *} \\
(0.170)\end{array}$ & $\begin{array}{c}0.630^{* * *} \\
(0.170)\end{array}$ & $\begin{array}{c}0.596^{* *} \\
(0.288)\end{array}$ & $\begin{array}{c}0.319^{* *} \\
(0.150)\end{array}$ \\
\hline Mig Share $_{s, t}$ & $\begin{array}{l}0.614^{*} \\
(0.315)\end{array}$ & $\begin{array}{c}1.140^{* *} \\
(0.459)\end{array}$ & $\begin{array}{c}1.317^{* *} \\
(0.529)\end{array}$ & $\begin{array}{c}0.613^{*} \\
(0.323)\end{array}$ & $\begin{array}{c}0.541 \\
(0.397)\end{array}$ & $\begin{array}{c}0.765^{* *} \\
(0.365)\end{array}$ & $\begin{array}{c}1.907^{* * *} \\
(0.567)\end{array}$ \\
\hline \multirow{5}{*}{$\begin{array}{l}\text { Observations } \\
\mathrm{Nb} \text {. states/CZs } \\
\text { R-squared }\end{array}$} & 306 & 204 & 276 & 276 & 282 & 228 & 3,688 \\
\hline & 51 & 51 & 46 & 46 & 47 & 38 & 741 \\
\hline & 0.993 & 0.990 & 0.993 & 0.993 & 0.993 & 0.995 & 0.895 \\
\hline & 10 Largest $\mathrm{B} 5$ & Quadratic $\mathrm{B} 7$ & \multicolumn{2}{|c|}{ Educ. level B8 } & \multicolumn{2}{|c|}{ Legal status B9 } & \\
\hline & (8) & (9) & $\begin{array}{c}(10) \\
\text { Ph.D }\end{array}$ & $\begin{array}{c}(11) \\
\text { Tertiary }\end{array}$ & $\begin{array}{c}(12) \\
\text { Docum. }\end{array}$ & $\begin{array}{c}(13) \\
\text { Undoc. }\end{array}$ & \\
\hline Mig Div Dit & $\begin{array}{c}0.617^{* * *} \\
(0.169)\end{array}$ & $\begin{array}{l}-0.131 \\
(1.954)\end{array}$ & $\begin{array}{c}0.262^{* *} \\
(0.103)\end{array}$ & $\begin{array}{c}0.369^{* * *} \\
(0.136)\end{array}$ & $\begin{array}{l}1.009^{* *} \\
(0.473)\end{array}$ & $\begin{array}{l}-0.153 \\
(0.127)\end{array}$ & \\
\hline Mig Share $_{s, t}$ & $\begin{array}{l}0.726^{*} \\
(0.365)\end{array}$ & $\begin{array}{l}0.622^{*} \\
(0.314)\end{array}$ & $\begin{array}{c}0.256 \\
(0.266)\end{array}$ & $\begin{array}{c}0.372 \\
(0.298)\end{array}$ & $\begin{array}{l}0.959^{*} \\
(0.535)\end{array}$ & $\begin{array}{l}4.426^{* *} \\
(2.140)\end{array}$ & \\
\hline$\left(\text { Mig Div } v_{s, t}\right)^{2}$ & & $\begin{array}{c}0.453 \\
(1.202)\end{array}$ & & & & & \\
\hline Observations & 306 & 306 & 306 & 306 & 204 & 204 & \\
\hline Nb. states & 51 & 51 & 51 & 51 & 51 & 51 & \\
\hline R-squared & 0.993 & 0.993 & 0.993 & 0.993 & 0.979 & 0.979 & \\
\hline \multicolumn{8}{|c|}{$\begin{array}{l}\text { Notes: }{ }^{* * *} \mathrm{p}<0.01,{ }^{* *} \mathrm{p}<0.05,{ }^{*} \mathrm{p}<0.1 \text {. Standard errors in parentheses are clustered at the state (or CZ) } \\
\text { level. A-indexed numbers in parentheses refer to full Tables provided in the Appendix. All models (except } \\
\text { col. 7) include the full vector of controls (not shown) with the } \log \text { of population }\left(\log \left(P o p_{s, t}\right)\right) \text {, the log of } \\
\text { urbanization }\left(\log \left(U r b_{s, t}\right)\right) \text { and the log of the average educational attainment of the working-age population } \\
\left(\log \left(H u m_{s, t}\right)\right) \text { as well as time and state fixed effects. }{ }^{\star} \text { The sample for col. } 7 \text { includes the geographical area } \\
\text { of } 50 \text { US states and the District of Columbia from } 1970 \text { to } 2010 \text {. The dependent variable is the logarithm of } \\
\text { the average wage of white US natives between } 40-50 \text {. }\end{array}$} \\
\hline
\end{tabular}

\subsection{Robustness checks}

This subsection investigates the robustness of the previous results. Table 2 summarizes the results for highskilled diversity. With the exception of the analysis by Commuting Zone (CZ), all regressions include the full set of time and state fixed effects and the set of covariates used in Table 1(b). The estimates for the covariates are not reported here; complete tables are provided in the Appendix. In addition, robustness checks for low-skilled diversity are reported in Table B1 in the Appendix. Irrespective of the specification we always find insignificant effects of low-skilled diversity on GDP per capita.

Robustness by subsample. - In Table 2, the benchmark results of Table 1(b) are reported in col. 1. In col. 2, we limit our sample to the 1970-2000 period, eliminating possible sources of variation prior to the 1965 amendments to the Immigration and Nationality Act, as well as variations driven by the recent evolution of diversity. Remember that Figure 1(b) shows that the average high-skilled diversity index slightly decreased 
between 2000 and 2010. Then, in col. 3 and 4, we examine whether the impact of diversity is driven by the size of the immigrant population: we drop the five US states with the greatest or the smallest immigration rates in 2010, respectively ${ }^{20}$ In col. 5, we investigate whether our results are driven by the Mexican diaspora, which represented $30 \%$ of the whole immigrant population of the US in 2010 . We drop the states located on the US-Mexican border, which host $62 \%$ of all Mexican immigrants to the US ${ }^{21}$ Remember that these states have experienced a drastic decrease in their diversity index (-40\% in low-skilled diversity between 1960 and 2010), which is entirely due to the rising inflows from Mexico ${ }^{22}$ Finally, in col. 6, we exclude the states in the first quartile (i.e. below Q1) of the 2010 distribution by immigrant population size.

Overall, we show that our FE results are robust to sample selection. In Table 2, the coefficient of high-skilled diversity is always positive, significant, and of the same order of magnitude as the benchmark estimates in col. 1. The positive impact becomes even larger when reducing the time span (0.87) or after excluding the states with the highest immigration rates (0.73). This suggests that high-skilled diversity could generate non-linear effects on macroeconomic performance; we will explore this hypothesis in col. 9 as well as in subsequent sections.

Robustness to the geographical unit of analysis. - In col. 7, we check whether our results hold when measuring diversity and immigration at the Commuting Zone (CZ) level, which better captures local labor market conditions. We use the CZ classification described in Dorn (2009). Since GDP per capita is not measurable at the $\mathrm{CZ}$ level, we follow Ottaviano and Peri (2006) and compute the logarithm of the average weekly earnings of white US natives aged 40 to 50 as a dependent variable. Unfortunately, using weekly earning forces us to restrict our sample to the 1970-2000 period due to data constraints on the number of weeks worked in the 1960 census. Remember the decades 1960s and 1970s include the years with the greatest sources of variation in birthplace diversity. Our results at the $\mathrm{CZ}$ level are qualitatively similar to those obtained at the state level. We find a positive and significant effect of high-skilled diversity on the weekly wages of natives although it becomes smaller and less significant.

Controlling for large groups. - We also investigate whether the effect of birthplace diversity is not driven by the presence of large diasporas characterized by specific productivity levels (this generalizes what we did when excluding states located on the US-Mexican border). In col. 8, we control for the state-specific shares of the ten largest origin countries in the US immigrant population. Controlling for the size of the largest immigrant groups affects neither the significance nor the magnitude of our coefficient of interest.

${ }^{20}$ The states with the greatest immigration rates are California, New York, Hawaii, New Jersey, and Florida. The states with the smallest rates are West Virginia, Mississippi, Kentucky, South Dakota, and Alabama.

${ }^{21}$ They include California, Texas, New Mexico, and Arizona.

${ }^{22}$ As an additional robustness check, we also drop the Mexican diaspora from the computation of the birthplace diversity index and the immigration rate, or we add the share of Mexican immigrants in the state as a separate variable. This increases the coefficients of high-skilled and low-skilled diversity, the latter becoming significant at the $5 \%$ level. Expanding the group of Mexican immigrants to all Hispanic immigrants gives the same results. See Table B7 in the Appendix. 
Quadratic specification. - When estimating the effect of genetic diversity on economic development, Ashraf and Galor (2013) and Ashraf et al. (2015) consider a quadratic specification, which allows them to identify an optimal level of genetic diversity. In our context, diversity may also induce costs and benefits, implying that its effect on macroeconomic performance could be better captured by an inverted-U shaped relationship. In col. 9, we thus supplement our benchmark specification by adding the square of the diversity index. If an optimal level of diversity among immigrants exists, we should find a positive coefficient for the linear term, and a negative coefficient for the squared term. We find no evidence of a quadratic effect of birthplace diversity. The coefficient for the squared index of diversity is insignificant in Table 2 Hence, this regression rejects the existence of an optimal level of diversity among college-educated immigrants.

Robustness by skill group. - One might be concerned that the positive effect of high-skilled diversity is driven by the presence of immigrants at the very top of the skill distribution. We investigate this issue in col. 10 and 11 of Table 2 We find insignificant differences when computing diversity on PhD graduates, or on other college-educated immigrants.

Robustness by legal status. - We also investigate the role of undocumented migration in governing the skill-specific effects of diversity. The US census counts every individual regardless of immigration status. Hence, undocumented immigrants influence our diversity index. This can be a source of concern as they are likely to be less educated than legal immigrants and to contribute differently to GDP, either because their productive activities are not recorded in the official GDP or because they are employed in jobs/sectors where skill complementarities are smaller. This could explain why the effect of low-skilled diversity is insignificant in most of our regressions. To explore this hypothesis, we use the "residual methodology" proposed by Borjas (2017) to identify the number of legal and undocumented immigrants by skill group. It consists in using individual characteristics to proxy the legal status of US immigrants. In this work, we use five characteristics (citizenship, employment industry, occupation, whether the individual receives any assistance, and the spouse's legal status ) and, due to data availability, we apply the residual methodology to the census years 1980 to 2010 . We thus compute the diversity indices on the legal and undocumented immigrant populations, and include them separately in our FE regressions in Col. 12 and 13 in Table 2. Distinguishing between legal and undocumented immigrants yields different effects. Diversity among undocumented immigrants has no significant effect, while diversity among legal immigrants has a positive and significant effect at the five\% level. On the contrary, controlling for the legal status of low-skilled immigrants does not modify our conclusions (see Table B1 in the Appendix). This confirms that the insignificant effect of low-skilled diversity cannot be attributed to the greater proportion of undocumented migrants in this group (on average, $17 \%$ for the US in 2010).

Robustness by age of entry. - The diversity indices used in our benchmark regressions are computed for the total population of working-age immigrants, whatever their age of entry in the US. As birthplace diversity conceivably reflects complementarities between individuals trained in different countries, it can be 
argued that immigrants who arrived in the US at different ages generate different levels of complementarity in skills and ideas with the native workforce. However, the role of the age of entry is unclear. On the one hand, immigrants with a longer foreign education are likely to bring more complementarities. On the other hand, immigrants who were partly educated in the US may have more transferable skills and a greater potential to interact with natives. To investigate this issue, we compute the diversity index using various samples of immigrants, and we include these alternative indices in Eq. (3). More precisely, we exclude from the immigrant population the individuals who arrived in the US before a given age threshold, which ranges from 5 to 25 in one-year intervals. For each skill group, Figure 3 reports the marginal effect of diversity and its confidence interval as a function of the age-of-entry threshold 23 As information on age of entry is not available in the 1960 census, our sample covers the 1970-2010 period. For this time span, the coefficients of the benchmark FE regressions (without controlling for age of entry) are equal to 0.835 for high-skilled diversity (significant at the $1 \%$ level), and to 0.088 for low-skilled diversity (insignificant). Whatever the ageof-entry threshold, the effect of low-skilled diversity is insignificant. Nevertheless, the age of entry matters for college graduates. Although the coefficient of high-skilled diversity is always positive and significant, the largest effects are obtained when the immigrant population includes individuals who arrived before age 20. Considering three age thresholds $(12,18$, and 22), Alesina et al. (2016) show that the positive effect of birthplace diversity slightly decreases when eliminating immigrant children, but always remains large and significant. Conversely, our results suggest that the greatest levels of complementarity are obtained when immigrants acquired primary and part of their secondary education abroad, and their college education in the US.

Additional robustness checks. - Many other robustness checks were carried out to validate our results and reinforce their interpretation. Some results can be found in the Appendix; others are available upon request. Firstly, one might be concerned that our results are driven by other dimensions of diversity that could be correlated with the variety of immigrants. In unreported regressions, we controlled for the racial or linguistic diversity within the native population. The results are unaltered.

Secondly, we also computed the diversity index after aggregating immigrants by continent or by broad region of origin. The results are available in Table B13 in the Appendix. Birthplace diversity then becomes insignificant. This reinforces our presumption that the effect of diversity captures skill complementarities that are driven by the heterogeneity in origin country characteristics. These complementarities are poorly captured when aggregating countries within a broad region.

Thirdly, we checked whether our results hold when using alternative measures of diversity. Table B7 in the Appendix shows that they hold when replacing our Herfindahl index by a Theil index of diversity. The advantage of the Theil index is that it can be decomposed into two additive components: a withinorigin component that captures changes in the concentration of immigrants at the intensive margin, and a between-origin component that captures changes in the concentration of immigrants at the extensive margin

\footnotetext{
${ }^{23}$ Comprehensive regression results are provided in Table B11 in the Appendix.
} 
Figure 3: Marginal effect of Mig Div s,t on $\log \left(y_{s, t}\right)$

Results for different age-of-entry thresholds (1970-2010)

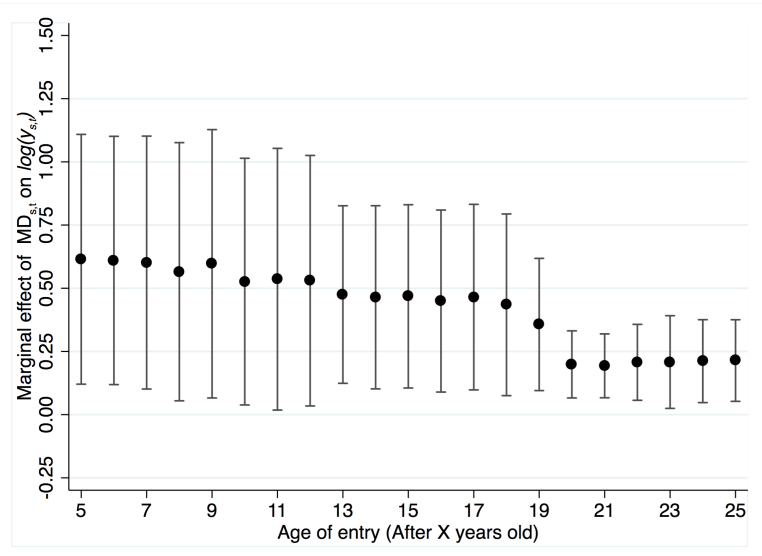

(a) High-skilled

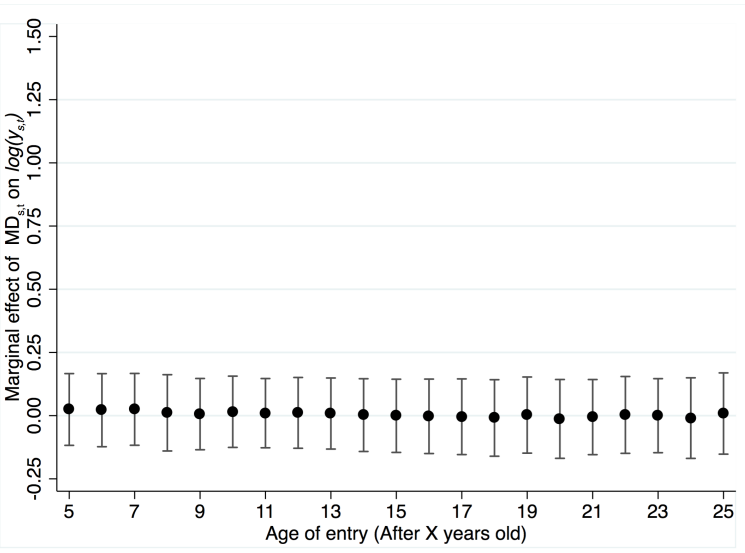

(b) Low-skilled

Notes: The two graphs report the marginal effect of $M i g \operatorname{Div}_{s, t}$ on $\log \left(y_{s, t}\right)$ when the immigrant population is restricted to individuals who arrived in the US after age $X$. Marginal effects are obtained using our main specification Eq. (3) which includes state and year fixed effects, as well as the immigration rate $\left(\right.$ Mig Share $\left._{s, t}\right)$, the log of population $\left(\log \left(\operatorname{Pop}_{s, t}\right)\right)$, the log of urbanization $\left(\log \left(U r b_{s, t}\right)\right)$ and the $\log$ of the average educational attainment of the working-age population $\left(\log \left(H_{u m}, t\right)\right)$. Source: Authors' elaboration on IPUMS data.

(see (Cadot et al. 2011)). Using this decomposition, we show that the positive effect of high-skilled diversity is driven by the intensive margin (i.e. by a more balanced mix of origin countries with positive stocks rather than by the entry of immigrants from new origin countries). In the same vein, our results hold when using a measure of cultural polarization. In Ager and Brückner (2013), Montalvo and Reynal-Querol (2003) and Montalvo and Reynal-Querol (2005), the index of polarization captures how far the distribution of a population is from the bimodal distribution. It is defined as:

$$
T P_{s, t}^{K}=1-\sum_{i=1}^{I}\left(\left(0.5-k_{i, s, t}^{K}\right) / 0.5\right)^{2} k_{i, s, t}^{K}
$$

Applied to the immigrant population (i.e. using $\widehat{k}_{i, s, t}^{K}$ instead of $k_{i, s, t}^{K}$ in the previous equation), the index $M P_{s, t}^{K}$ is maximized when there are two groups of immigrants which are of equal size (i.e. 50\%). For US states, the polarization index exhibits a correlation of -0.89 with the diversity index (this is much greater than the correlation reported in Ager and Brückner (2013)). Hence, including these two variables in the same regression is risky. As shown in Table $\mathrm{B} 7$ in the Appendix, replacing $M D_{s, t}^{K}$ by $M P_{s, t}^{K}$ gives the same results as in our benchmark regression but with the opposite sign.

Fourthly, we investigated whether the same effects of diversity are obtained when considering alternative 
proxies for macroeconomic performance. In particular, population and employment levels may also react to changes in total factor productivity. In unreported regressions, we did not find any significant effect of diversity on the log of employment or population as a dependent variable. This might be due to the fact that, in a context with mobility costs and with two types of workers, the relationship between productivity growth and aggregate population/employment growth is less mechanical than in a context with perfect labor mobility and one class of workers. Our results do not support an influence of diversity beyond the income effect.

Finally, we tested whether the size of skill complementarities between diverse immigrants can be attenuated by the cultural distance between them. Our birthplace diversity index $M D_{s, t}^{K}$ does not account for the cultural distance between origin and destination countries. It assumes that all groups are culturally equidistant from each other. We considered an adjusted index that multiplies the probability that two randomly-drawn immigrants were born in two different countries by a measure of cultural distance between these two countries. For the latter, we used the database on genetic distance of Spolaore and Wacziarg (2009). Genetic distance is based on blood samples and proxies the time since two populations had common ancestors. Again, the results reported in Appendix G are robust to the use of an adjusted diversity index.

\subsection{Dealing with endogeneity}

In this section, we investigate the likelihood that our results are driven by reverse causality. We use placebo regressions in sub-section 4.3.1 and IV regressions in sub-section 4.3.2. treating birthplace diversity, immigration rates and epidemiological terms as potentially endogenous variables ${ }^{24}$

\subsubsection{Placebo regressions}

We now investigate whether our results can be driven by reverse causality (i.e. growing states attracting more diverse immigrants). If diversity increases with economic prosperity, we can expect a positive correlation between birthplace diversity among American workers and GDP per capita, as explained in Section 3 . In our placebo regressions, we augment the benchmark model with two additional control variables, namely the natives' migration rates $\left(n_{s, t}^{K}\right)$ and the measures of diversity computed for the native population $\left(N D_{s, t}^{K}\right)$. Since the range of variation of the diversity indices for immigrants and natives are different, we standardize $N D_{s, t}^{K}$ in such a way that it exhibits the same mean and standard deviation as $M D_{s, t}^{K}$.

\footnotetext{
${ }^{24}$ Another issue relates to self-selection if immigrants from different source countries have unobserved characteristics and traits that are conducive to economic growth and that are captured by the diversity index. We deal with this omitted variable issue in Table E1 in the Appendix. First, we follow Alesina et al. (2016) and assume that self-selection on unobserved productive traits can be proxied by self-selection on observable characteristics. We construct an index of selection on educational attainment in that we include it in the benchmark specification. Still, it could be possible that self-selection on unobserved traits is poorly captured by self-selection on educational attainment. Thus, we extend the analysis above and follow the methodology proposed by Oster (2016) on the likelihood of an omitted variable problem due to self-selection
} 
Table 3: Mig Div s,t v.s diversity among "native immigrants" Nat Div $v_{s, t}$ Results by skill group $\left(\operatorname{Dep}=\log \left(y_{s, t}\right)\right)$

\begin{tabular}{|c|c|c|c|c|c|c|}
\hline Skill level & $\begin{array}{c}(1) \\
\text { High skilled }\end{array}$ & $\begin{array}{c}(2) \\
\text { High skilled }\end{array}$ & $\begin{array}{c}(3) \\
\text { High skilled }\end{array}$ & $\begin{array}{c}(4) \\
\text { Low skilled }\end{array}$ & $\begin{array}{c}(5) \\
\text { Low skilled }\end{array}$ & $\begin{array}{c}(6) \\
\text { Low skilled }\end{array}$ \\
\hline Mig Div $v_{s, t}$ & $\begin{array}{c}0.616^{* * *} \\
(0.160)\end{array}$ & & $\begin{array}{c}0.432^{* *} \\
(0.168)\end{array}$ & $\begin{array}{c}0.141 \\
(0.086)\end{array}$ & & $\begin{array}{l}0.156^{*} \\
(0.082)\end{array}$ \\
\hline Mig Share $_{s, t}$ & $\begin{array}{l}0.614^{*} \\
(0.315)\end{array}$ & & $\begin{array}{c}1.008^{* * * *} \\
(0.347)\end{array}$ & $\begin{array}{l}0.481^{*} \\
(0.282)\end{array}$ & & $\begin{array}{c}0.642^{* *} \\
(0.278)\end{array}$ \\
\hline Nat Div $v_{s, t}$ & & $\begin{array}{c}0.719 \\
(0.486)\end{array}$ & $\begin{array}{l}0.879^{*} \\
(0.492)\end{array}$ & & $\begin{array}{c}0.139 \\
(0.174)\end{array}$ & $\begin{array}{c}0.157 \\
(0.172)\end{array}$ \\
\hline Nat Share $s, t$ & & $\begin{array}{c}0.376^{* *} \\
(0.167)\end{array}$ & $\begin{array}{c}0.428^{* *} \\
(0.203)\end{array}$ & & $\begin{array}{c}0.059 \\
(0.242)\end{array}$ & $\begin{array}{c}0.218 \\
(0.244)\end{array}$ \\
\hline $\log \left(P_{o p} p_{s, t}\right)$ & $\begin{array}{c}-0.155^{* *} \\
(0.075)\end{array}$ & $\begin{array}{c}-0.135^{*} \\
(0.068)\end{array}$ & $\begin{array}{c}-0.176^{* *} \\
(0.073)\end{array}$ & $\begin{array}{c}-0.166^{* *} \\
(0.081)\end{array}$ & $\begin{array}{c}-0.120^{*} \\
(0.067)\end{array}$ & $\begin{array}{c}-0.169^{* *} \\
(0.073)\end{array}$ \\
\hline $\log \left(U r b_{s, t}\right)$ & $\begin{array}{c}0.285^{* *} \\
(0.135)\end{array}$ & $\begin{array}{l}0.294^{*} \\
(0.159)\end{array}$ & $\begin{array}{c}0.316^{* *} \\
(0.149)\end{array}$ & $\begin{array}{c}0.329^{* *} \\
(0.163)\end{array}$ & $\begin{array}{c}0.266 \\
(0.164)\end{array}$ & $\begin{array}{l}0.304^{*} \\
(0.172)\end{array}$ \\
\hline $\log \left(H u m_{s, t}\right)$ & $\begin{array}{c}0.759^{* * *} \\
(0.197)\end{array}$ & $\begin{array}{c}0.557^{* *} \\
(0.213)\end{array}$ & $\begin{array}{c}0.477^{* *} \\
(0.217)\end{array}$ & $\begin{array}{c}0.807^{* * *} \\
(0.205)\end{array}$ & $\begin{array}{c}0.677^{* *} \\
(0.271)\end{array}$ & $\begin{array}{l}0.505^{*} \\
(0.269)\end{array}$ \\
\hline Constant & $\begin{array}{c}7.348^{* * * *} \\
(1.262)\end{array}$ & $\begin{array}{c}7.058^{* * * *} \\
(1.377)\end{array}$ & $\begin{array}{c}7.091^{* * *} \\
(1.389)\end{array}$ & $\begin{array}{c}7.662^{* * * *} \\
(1.263)\end{array}$ & $\begin{array}{c}7.493^{* * *} \\
(0.988)\end{array}$ & $\begin{array}{c}8.049^{* * *} \\
(1.027)\end{array}$ \\
\hline Observations & 306 & 306 & 306 & 306 & 306 & 306 \\
\hline Nb. states & 51 & 51 & 51 & 51 & 51 & 51 \\
\hline R-squared & 0.993 & 0.993 & 0.993 & 0.993 & 0.993 & 0.993 \\
\hline Time fixed effects & Yes & Yes & Yes & Yes & Yes & Yes \\
\hline States fixed effects & Yes & Yes & Yes & Yes & Yes & Yes \\
\hline
\end{tabular}

Table 3 reports the results of our placebo regressions: internal immigration rates are positively correlated with GDP per capita. However, the native diversity index is insignificant (or weakly significant in col. 3). Although these placebo tests do not necessarily imply that diversity among foreign immigrants is not affected by macroeconomic performance, they mitigate the risk of a strong reverse causation relationship.

\subsubsection{Two-stage Least-Squares}

We now check whether our results hold when instrumenting our main variables of interest. Table 4 provides the results of our 2SLS regressions. In col. 1, 2, 6 and 7, we only instrument our main variable of interest, $M D_{s, t}^{K}$, and use the two IV strategies explained in subsection 3.2 . The first one is a shift-share strategy, which uses the predicted diversity index based on the 1960 geographic structure of each diaspora. The second one is the gravity-like strategy a la Feyrer (2019). First-stage estimates are provided in Tables D2 and D3 in the Appendix. Then, in the remaining columns, we deal with the endogeneity of two other important regressors, the immigration rate $\left(m_{s, t}^{K}\right)$ and the epidemiological term $\left(M Y_{s, t}^{K}\right)$. To do so, we use the gravity-like strategy a la Feyrer (2019) only.

Col. 1 and 2 in Table 4 confirm our previous findings for high-skilled diversity when $M D_{s, t}^{H}$ is instrumented only. The effect of $M D_{s, t}^{H}$ is always positive and highly significant. When using the shift-share on unobservables. In both cases we find that self-selection is unlikely to drive our results. 
strategy (col. 1), the magnitude of the coefficient is close to that of the FE regressions. The coefficient becomes larger under the gravity-like strategy a la Feyrer (2019) (col. 2) even if it is not significantly different from the FE estimate. It is worth noticing that the instruments used in our IV regressions are valid. In particular, the Kleibergen-Paap F-stat of our second stage is always very large, and satisfies the Stock-Yogo critical values related to $10 \%$ maximal IV size. In addition, the F-test of the first stage is always above the critical value of 10 . After instrumenting with the shift-share strategy, a $10 \%$ change in diversity induces a $5.1 \%$ change in GDP; equivalently, a one-standard-deviation change in high-skilled diversity increases GDP per capita by $2.8 \%$, which is close to our benchmark results. As for low-skilled diversity, we find insignificant or weakly significant effects in col. 6 and 7. We conduct additional IV regressions to deal with the endogeneity of the immigration rate and of the epidemiological term in the remaining columns of Table 4 As the shift-share strategy does a poor job of predicting the immigration rate 25 we only use the gravity-like strategy a la Feyrer (2019). Different combinations of endogenous regressors are considered and they all give rise to the same conclusions. In all specifications, the instrumental variables are strong. Our estimates for $M D_{s, t}^{H}$ are robust, and the magnitude of the coefficient is similar to the FE estimates. The effect of low-skilled diversity is always insignificant from col. 8 to 10 . Under some specifications, we obtain a negative and significant epidemiological effect for both college-educated and low-skilled immigrants. Again, we find no evidence of a contamination effect. On the contrary, our epidemiological results are more in line with the effect of diversity: attracting immigrants from economically and culturally distant countries is beneficial for economic growth. Overall, our IV regressions support the view that increasing birthplace diversity among college-educated immigrants causes a rise in GDP per capita in the receiving state.

\subsection{Channels of transmission}

In this section, we investigate the channels of transmission through which birthplace diversity affects economic growth, as well as the conditions under which the effect of diversity is maximized. To mitigate endogeneity concerns, we use the gravity-like IV strategy a la Feyrer (2019) and instrument the diversity index as well as the share of immigrants ${ }^{26}$

\footnotetext{
${ }^{25}$ The same problem arises in Alesina et al. $(2016)$.

${ }^{26}$ Contrary to the shift-share, the gravity-like strategy provides valid instruments for the two variables of interest.
} 


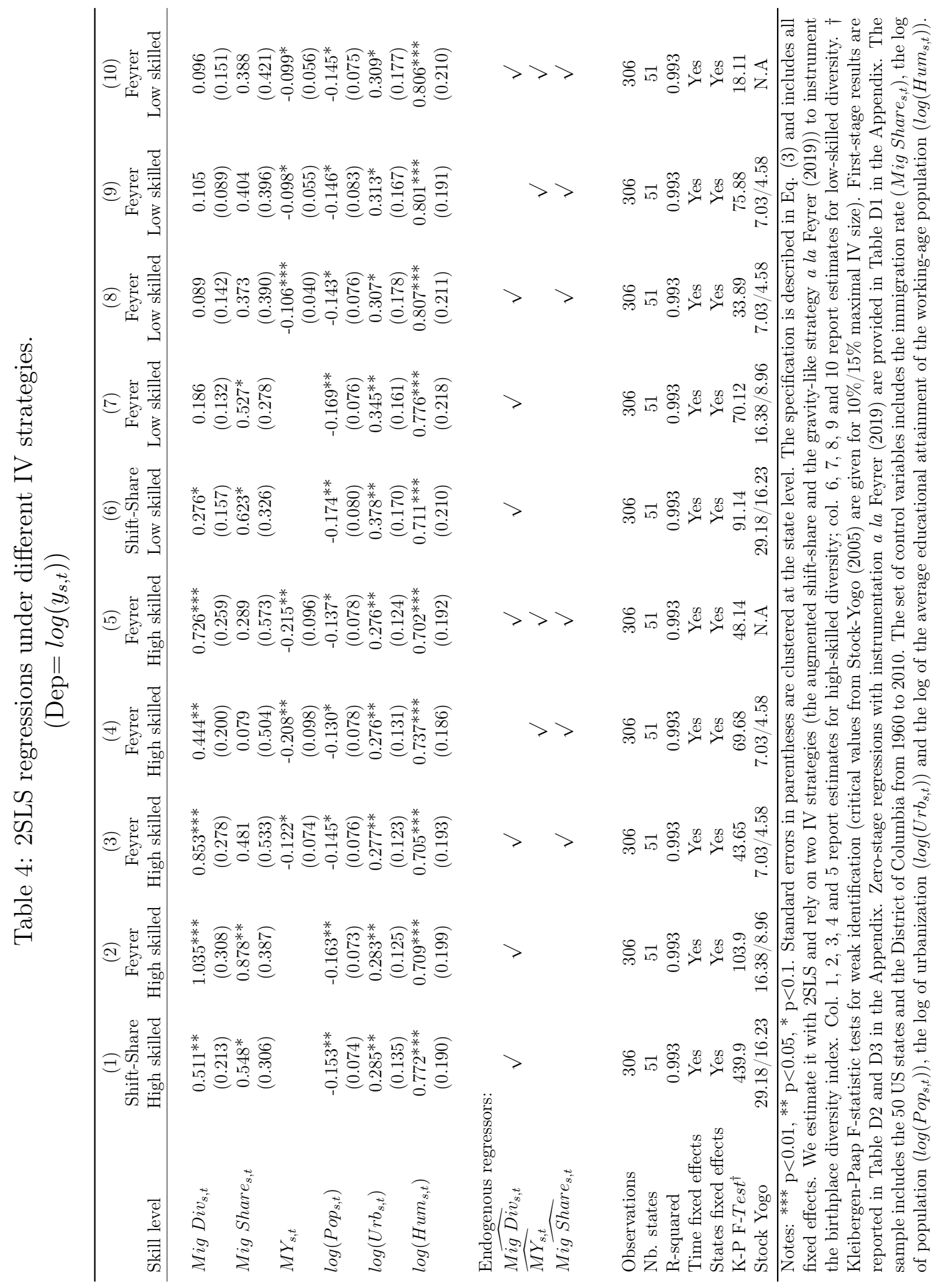




\subsubsection{Alternative dependent variables}

We first produce exploratory regressions using alternative dependent variables. These dependent variables include alternative outcomes of interest or intermediate variables influencing the level and/or growth rate of GDP per capita. We only focus on the effects of high-skilled diversity and of the share of immigrants in the college-educated population. We are aware that each of these alternative regressions should ideally include a specific set of appropriate controls. Nevertheless, for the sake of comparison, we use a common specification including the full set of fixed effects without time-varying controls. The results of these exploratory regressions are described in Table 5, which starts with the (benchmark) effect on GDP per capita in col. 1.

We first test whether diversity impacts the average employment rate in the receiving state. A positive effect on employment can be obtained if diversity stimulates linkages between sectors and firms, and/or if it increases labor productivity (Peri (2012)). We use census data from IPUMS to construct our aggregate measure of employment rate at the state level. The results in col. 2 show that high-skilled diversity does not significantly affect the log of the employment rate.

Secondly, we investigate the effect of high-skilled diversity on the performance of the R\&D sector. A positive effect on innovation can be obtained if diversity enhances complementarities in R\&D activities and improves the collective ability to solve problems. Such complementarities have been identified in the existing literature. Hunt and Gauthier-Loiselle (2010) show that the number of patents per capita increases with the number of college-educated immigrants in US states. Looking at the US Age of Mass Migration, Sequeira et al. (2017) find that immigration increases the number of patents registered by natives and foreigners. We use data from the US Patent and Trademark Office and compute the number of patents per capita for each state and for each decade. In col. 3, we find that high-skilled diversity increases the log number of patents per capita.

Thirdly, we examine whether diversity affects social capital. It can be the case that the economic gains from diversity are partly compensated for by a negative effect on trust, reciprocity or cooperation between people. We proxy social capital using data on violence and other criminal offences. We extract data from the US Department of Justice on the numbers of violent crimes and property crimes per capita, by state and by decade ${ }^{27}$ In col. 4 and 5, we show that high-skilled diversity does not significantly affect the crime rate. Interestingly, the level of high-skilled immigration is negatively associated with the number of property crimes.

Fourthly, we assess whether the rise in GDP per capita benefits native workers or immigrants only. Recent studies on the labor market effect of immigration show that native and immigrant workers in a given skill-experience group are imperfect substitutes (Ottaviano and Peri (2012), Manacorda et al. (2012), Card (2012)). The estimated elasticity of substitution varies across countries. We test whether birthplace diversity increases the level of labor market complementarities between immigrants and natives. To do so,

\footnotetext{
${ }^{27}$ Violent crimes include murders, non negligent manslaughters, rapes, robberies and aggravated assaults. Property crimes include burglaries, larceny-thefts and motor vehicle thefts, among others.
} 
Table 5: Transmissions channels for high-skilled diversity IV gravity-like strategy a la Feyrer $(2019)\left(\mathrm{Dep}=\log \left(y_{s, t}\right)\right)$

\begin{tabular}{|c|c|c|c|c|c|}
\hline & $\begin{array}{c}(1) \\
\text { GDP cap (log) }\end{array}$ & $\begin{array}{c}(2) \\
\text { Employment (log) }\end{array}$ & $\begin{array}{c}(3) \\
\text { Patents (log) }\end{array}$ & $\begin{array}{c}(4) \\
\text { Violent crime }(\log )\end{array}$ & $\begin{array}{c}(5) \\
\text { Property crime (log) }\end{array}$ \\
\hline Mig Div $v_{s, t}$ & $\begin{array}{c}1.063^{* * *} \\
(0.377)\end{array}$ & $\begin{array}{c}0.056 \\
(0.066)\end{array}$ & $\begin{array}{l}3.011^{* *} \\
(1.461)\end{array}$ & $\begin{array}{c}0.894 \\
(1.279)\end{array}$ & $\begin{array}{l}0.923^{*} \\
(0.531)\end{array}$ \\
\hline Mig Share $_{s, t}$ & $\begin{array}{c}0.054 \\
(0.755)\end{array}$ & $\begin{array}{l}-0.131 \\
(0.081)\end{array}$ & $\begin{array}{l}3.277^{*} \\
(1.963)\end{array}$ & $\begin{array}{l}-1.531 \\
(1.696)\end{array}$ & $\begin{array}{c}-1.912^{* *} \\
(0.893)\end{array}$ \\
\hline Observations & 306 & 306 & 306 & 306 & 306 \\
\hline R-squared & 0.991 & 0.773 & 0.315 & 0.822 & 0.848 \\
\hline Nb. states & 51 & 51 & 51 & 51 & 51 \\
\hline Time fixed effects & Yes & Yes & Yes & Yes & Yes \\
\hline States fixed effects & Yes & Yes & Yes & Yes & Yes \\
\hline K-P F-Test ${ }^{\dagger}$ & 49.70 & 49.70 & 49.70 & 49.70 & 49.70 \\
\hline \multirow[t]{2}{*}{ Stock Yogo } & $7.03 / 4.58$ & $7.03 / 4.58$ & $7.03 / 4.58$ & $7.03 / 4.58$ & $7.03 / 4.58$ \\
\hline & $\begin{array}{c}(6) \\
\text { Wages HS }(\log )^{*}\end{array}$ & $\begin{array}{c}(7) \\
\text { Wages LS }(\log )^{*}\end{array}$ & $\begin{array}{c}(8) \\
\text { Diversity occ. HS }\end{array}$ & $\begin{array}{c}(9) \\
\text { Diversity occ. LS }\end{array}$ & \\
\hline Mig Div $v_{s, t}$ & $\begin{array}{c}0.553^{*} \\
(0.286)\end{array}$ & $\begin{array}{c}0.718^{* *} \\
(0.347)\end{array}$ & $\begin{array}{l}-0.004 \\
(0.013)\end{array}$ & $\begin{array}{c}0.001 \\
(0.040)\end{array}$ & \\
\hline Mig Share St, & $\begin{array}{l}0.685^{*} \\
(0.359)\end{array}$ & $\begin{array}{c}0.555 \\
(0.364)\end{array}$ & $\begin{array}{c}0.014 \\
(0.014)\end{array}$ & $\begin{array}{c}-0.148^{* * *} \\
(0.054)\end{array}$ & \\
\hline Observations & 255 & 255 & 306 & 306 & \\
\hline Nb. states & 51 & 51 & 51 & 51 & \\
\hline R-squared & 0.824 & 0.608 & 0.911 & 0.384 & \\
\hline Time fixed effects & Yes & Yes & Yes & Yes & \\
\hline States fixed effects & Yes & Yes & Yes & Yes & \\
\hline K-P F-Test ${ }^{\dagger}$ & 30.02 & 30.02 & 49.70 & 49.70 & \\
\hline Stock Yogo & $7.03 / 4.58$ & $7.03 / 4.58$ & $7.03 / 4.58$ & $7.03 / 4.58$ & \\
\hline $\begin{array}{l}\text { Notes: } * * * \mathrm{p}<0.01 \text {, } \\
\text { the } 50 \text { US states al } \\
\text { dependent variable, } \\
\text { in the } 1960 \text { US cen } \\
\text { using IPUMS data } \\
\text { utility patents per c } \\
\text { from the U.S. Depa } \\
\text { including murder ar } \\
\text { reports the total nu } \\
\text { theft. Following Bo } \\
\text { Diversity Occ. is th } \\
\dagger \text { Kleibergen-Paap } \\
\text { maximal IV size). V } \\
\text { the share of immigr }\end{array}$ & $\begin{array}{l}{ }^{* *} \mathrm{p}<0.05,{ }^{*} \mathrm{p}<0.1 \\
\text { nd the District of } \\
\text { the sample is redu } \\
\text { sus. Data for GDP } \\
\text { and report the nu } \\
\text { apita (patents for } \mathrm{i} \\
\text { artment of justice. } \\
\text { ad non negligent m } \\
\text { Imber of property } \\
\text { rjjas 2015, wages } \\
\text { ee probability that } \\
\text { F-statistic tests for } \\
\text { We use the gravity-l } \\
\text { ants. }\end{array}$ & $\begin{array}{l}\text { 1. Standard errors in } \\
\text { Columbia from } 1960 \\
\text { uced to } 255 \text { observat } \\
\text { are provided by the } \\
\text { mber of workers in } \\
\text { invention) granted by } \\
\text { Violent crime report } \\
\text { anslaughter, legacy a } \\
\text { crimes per capita in } \\
\text { are measured as the } \\
\text { two randomly draw } \\
\text { r weak identification } \\
\text { like strategy a la Fey }\end{array}$ & $\begin{array}{l}\text { parentheses are clu } \\
\text { to } 2010 .\left(^{*}\right) \text { Wher } \\
\text { ions since data on t } \\
\text { Bureau of Econom } \\
\text { the total labor force } \\
\text { y the U.S. Patent an } \\
\text { ts the total number } \\
\text { nd revised rape, rol } \\
\text { a given state includ } \\
\text { log of natives' wee } \\
\text { n individuals in a st } \\
\text { (critical values fror } \\
\text { rer 2019) to jointly }\end{array}$ & $\begin{array}{l}\text { stered at the state le } \\
\text { the logarithm of w } \\
\text { he number of weeks } \\
\text { ic Analysis. Employ } \\
\text { Patents are the d } \\
\text { d Trademark Office. } \\
\text { of violent crimes pe } \\
\text { bery and aggravated } \\
\text { ing burglary, larceny } \\
\text { kly wages (males and } \\
\text { ate are working in t } \\
\text { m Stock-Yogo (2005) } \\
\text { instrument the birth }\end{array}$ & $\begin{array}{l}\text { el. The sample includes } \\
\text { kly wages is used as a } \\
\text { orked are not included } \\
\text { lent data are computed } \\
\text { ennial total number of } \\
\text { Data on crime are taken } \\
\text { capita in a given state } \\
\text { assault. Property crime } \\
\text { heft and motor vehicle } \\
\text { females aged } 15 \text { to } 64 \text { ). } \\
\text { o different occupations. } \\
\text { are given for } 10 \% / 15 \% \\
\text { lace diversity index and }\end{array}$ \\
\hline
\end{tabular}

we use the log of natives' earnings as a dependent variable. In line with Borjas (2015), we use census data to compute the average weekly wages of native workers by state, by education level, and for the years 1970 to 2010. Data on the number of weeks worked are not available for the census year 1960. Our sample includes all natives aged 15 to 64 irrespective of their gender. In col. 6 and 7, we find a positive and significant effect of high-skilled diversity on the log of natives' earnings. The effect is larger and more significant for low-skilled natives than for the highly skilled. Overall, these results suggest that diversity governs the size of skill complementarities between native and foreign workers.

Finally, to push the analysis of complementarities one step further, we investigate whether birthplace diversity increases the level of occupational diversity in the state of destination. Workers with a foreign 
background are more likely to start new businesses and to overcome labor shortages in certain sectors or occupations. Using IPUMS data, we compute an index of occupational fractionalization by state and by decade. This index measures the probability that two randomly drawn workers are employed in two different occupations. As many occupations are skill-specific, we compute separate indices for the two skill groups. In col. 8 and 9, we find that the effect of birthplace diversity on occupational fractionalization is insignificant. This result can be driven by the fact that occupational data are available at a low level of detail.

\subsubsection{Drivers of skill complementarities}

Our Herfindahl index does not account for the economic, cultural, linguistic, or institutional distance between the origin countries and the US. When adding separate epidemiological terms, we obtain insignificant or negative effects. This suggests that attracting migrants from distant countries is beneficial for growth on average. We now explore whether the interaction between diversity and origin country characteristics matters by using the Greenberg diversity indices defined in Eq. 5 . The Greenberg index accounts for the cultural and economic distances between the origin country and the US (with weights equal to $\theta_{1}$ and $\theta_{2}$, respectively). When $\theta_{1}$ increases (for a given $\theta_{2}$ ), the Greenberg index over-weights immigrants from culturally distant countries (i.e. from genetically or linguistically distant countries). When $\theta_{2}$ increases (for a given $\theta_{1}$ ), it overweights immigrants from richer countries (i.e. from less economically distant countries). Hence, we estimate our benchmark specification using the Greenberg (augmented) diversity index under various combinations of $\theta_{1}$ and $\theta_{2}$ (ranging from -10 to +10 ). This helps us identify whether and how origin country characteristics influence the size of skill complementarities between immigrants and natives. For every combination of $\theta_{1}$ and $\theta_{2}$, we instrument the Greenberg index using the gravity-like strategy a la Feyrer (2019) 28

The results for high-skilled diversity are presented in Figures 5(a) and 5(b) (i.e. the top panel); the results for low-skilled diversity are presented in Figures 5(c) and 5(d) (i.e. the bottom panel). In the left panel, we use genetic distance as a proxy for cultural distance; in the right panel, we use linguistic distance. We only plot the standardized coefficients of augmented diversity that are statistically significant at the $5 \%$ level. The shade of grey is proportional to the magnitude of the effect: darker cells correspond to a greater effect of diversity (i.e., the combinations of $\theta_{1}$ and $\theta_{2}$ generating greater effects on income per capita). Conversely, lighter cells correspond to a smaller effect, and the coefficients that are not significant at the $5 \%$ level do not appear (white color).

Figures $5(\mathrm{a})$ and $5(\mathrm{~b})$ show the results for high-skilled diversity. When holding cultural distance constant $\left(\theta_{1}=0\right)$, over-weighting migrants from economically distant countries $\left(\theta_{2}<0\right)$ increases the significance and the magnitude of the effect of diversity. This suggests that hosting immigrants from economically distant countries brings complementary skills to the state of destination. On the contrary, over-weighting immigrants from richer countries $\left(\theta_{2}>0\right)$ leads to smaller results. In the same vein, when holding economic distance constant $\left(\theta_{2}=0\right)$, over-weighting genetically or linguistically distant groups $\left(\theta_{1}>0\right)$ increases

\footnotetext{
${ }^{28}$ In all regressions the Kleibergen-Paap F-statistic is above the critical values from Stock-Yogo (2005).
} 
Figure 4: Augmented Diversity Index

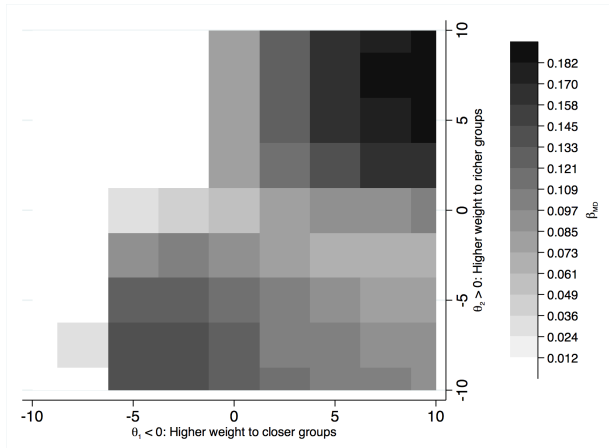

(a) Genetic distance, High-skilled

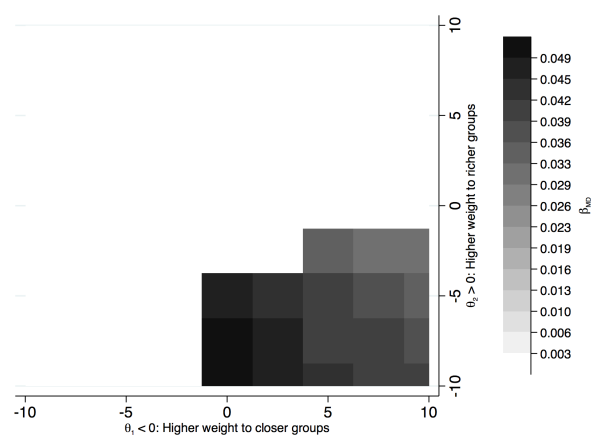

(c) Genetic distance, Low-skilled

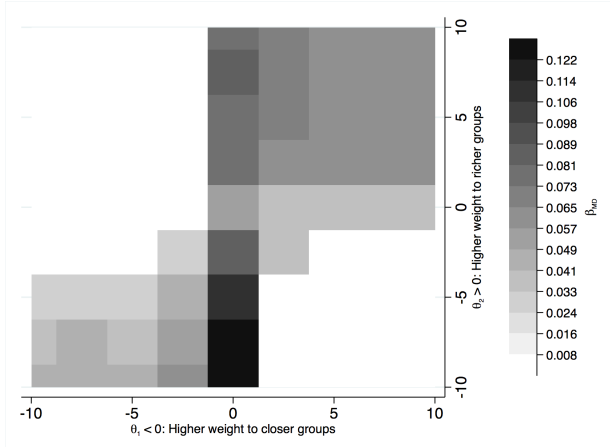

(b) Linguistic distance, High-skilled

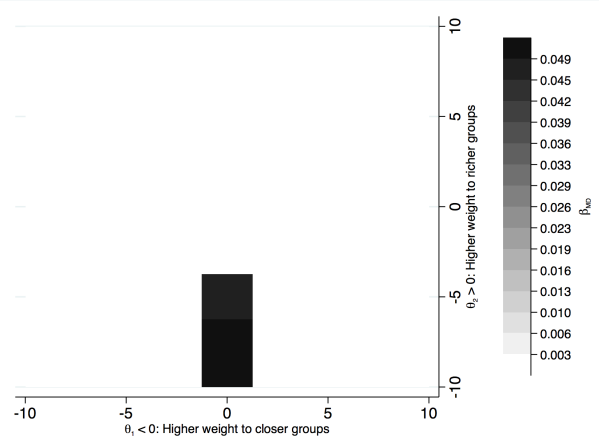

(d) Linguistic distance, Low-skilled

Notes: Diversity among immigrants is defined as in Eq. (5). Each squared cell represents one estimated coefficient for $M D_{s, t}^{K, A u g}$, which itself corresponds to a particular combination of $\theta_{1}$ and $\theta_{2}$. Blank squared cells represent insignificant coefficients at the $5 \%$ level. Each shaded cell corresponds to a significant coefficient at the $5 \%$ level, and darker cells mean larger estimated coefficients. Data on genetic distance are obtained from Spolaore and Wacziarg (2009). Data on linguistic distance are obtained from Head et al. (2010). We use a dummy equal to one if a language is spoken by at least $9 \%$ of the population in both countries. Source: Authors' elaboration on IPUMS data.

the significance and magnitude of the effect of diversity. This suggests that cultural distance increases the effect of diversity. At $\theta_{2}=0$, overweighting migrants that are linguistically close to US citizens leads to insignificant results.

Economic and cultural distances are correlated. Nevertheless, looking at the interactions between them sheds light on the benefits from diversity and on the size of potential skill complementarities. Over-weighting groups that are richer (i.e., economically closer) and culturally closer to natives always induces insignificant results (top-left area of the figure). On the contrary, the greatest gains from diversity are obtained when considering groups that are economically close to and culturally distant from natives (top-right area of the figures). To a lesser extent, it is also growth-enhancing to attract high-skilled immigrants from culturally close and economically distant countries (bottom-left area of the figure). Hence, cultural distance is beneficial 
for the highly skilled when they originate from richer countries. Overall, in line with our skill complementarity hypothesis, diversity is beneficial when immigrants originate from economically OR culturally distant countries (but not both). These results hold when using genetic or linguistic distance as a cultural proxy.

These findings partially hold for low-skilled diversity. Figures $5(\mathrm{c})$ and $5(\mathrm{~d})$ show that low-skilled diversity can also be growth-enhancing when immigrants come from economically distant countries. On the contrary, the effect is always insignificant when over-weighting immigrants from richer countries. Significant and positive effects are obtained when immigrants originate from poor and genetically distant countries $\left(\theta_{2}<0\right.$ and $\theta_{1}>0$ ). This result is not confirmed when using linguistic distance. Contrary to high-skilled diversity, we do not find evidence of a positive effect of attracting low-skilled migrants from countries that are economically close but culturally similar. Cultural proximity among the low skilled is never growth-enhancing, although we have not found any significant and negative effect associated with high cultural distance.

\section{Conclusions}

This paper empirically investigates the impact of birthplace diversity on economic growth. We use a rich data set that covers all US states in the post-World War II period. Compared to existing studies, we take advantage of the availability of panel data to conduct a large set of robustness checks and to better deal with unobserved heterogeneity and other endogeneity issues. We systematically test for skill-specific effects of diversity. Using a full set of fixed effects and combining various identification strategies, we show that diversity among college-educated immigrants positively and monotonically affects the macroeconomic performance of US states. This result is highly robust to the measurement of diversity, to sample selection, to specification choices and to the instrumentation strategy. Contrary to existing studies, diversity among less educated immigrants induces insignificant effects (or much smaller gains in certain limited circumstances). The latter result holds when we control for the share of undocumented migrants in this group. Still, we find no evidence of an immigration-driven contamination by bad economic and/or institutional conditions in origin countries.

Further important innovations are that we explore the channels of transmission through which diversity affects economic growth, and we identify the conditions under which the gains from high-skilled diversity are maximized. We provide converging evidence pointing at the existence of skill complementarities between workers trained in different countries. These synergies are observed on the labor market, and in the R\&D sector. We show that high-skilled diversity increases the decennial number of patents per capita and the average weekly income of low-skilled and high-skilled natives. The effect is maximized when immigrants originate from economically or culturally distant countries (but not both), and when they acquired part of their secondary education abroad and their college education in the US. In terms of magnitude, a $10 \%$ increase in diversity among college-educated immigrants raises GDP per capita by about $6 \%$, which is greater than in recent studies. This implies that high-skilled diversity explains $3.5 \%$ of the output rise between 1960 
and 2010 in the US, and about $4 \%$ of the current output gap between the least and most diverse states.

Obviously, focusing on the US states over a specific period raises the problem of external validity of our results. For example, there is no guarantee that diversity shocks propelled by Africa-to-Europe migration or by intra-European mobility have generated the same economic responses. However, the cross-country analysis conducted in the online appendix suggests that similar mechanisms are likely to operate in the other OECD countries.

\section{References}

Ager, P., and Brückner, M. (2013). Cultural diversity and economic growth: Evidence from the US during the age of mass migration. European Economic Review, 64:76-97.

Alesina, A., Harnoss, J. and Rapoport, H. (2016). Birthplace diversity and economic prosperity. Journal of Economic Growth, 21:101-138.

Alesina, A., and La Ferrara, E. (2005). Ethnic diversity and economic performance. Journal of Economic Literature, 43(3):762-800.

Angrist J, and Pischke, J-S. (2009). Mostly Harmless Econometrics: An Empiricist's Companion. Princeton University Press (392 p.).

Artuc, E., Docquier, F., Özden, C., and Parsons, C. (2015). A Global Assessment of Human Capital Mobility: The Role of Non-OECD Destinations. World Development, 65(1):6-26.

Ashraf, Q., and Galor, O. (2013). The Out of Africa hypothesis, Human genetic diversity, and comparative economic development. American Economic Review, 103(1):1-46.

Ashraf, Q., Galor, O., and Klemp, M. (2015). The Out of Africa hypothesis of comparative development reflected by nighttime light intensity. Working Paper No. 2014-4, Brown University, Departments of Economics.

Aubry, A., Burzyński, M., and Docquier, F. (2016). The welfare impact of global migration in OECD countries. Journal of International Economics, 101:1-21.

Barro, R \& J. Lee (2013). A New Data Set of Educational Attainment in the World, 1950-2010 Journal of Development Economics, 104:184-198

Barsbai T., Rapoport, H., Steinmayr, A., and Trebesch, C. (2017). The effect of labor migration on the diffusion of democracy: Evidence from a former Soviet Republic. American Economic Journal: Applied Economics, 9(3):36-69. 
Beine, M., Docquier, F., and Schiff, M. (2013). International migration, transfer of norms and home country fertility. Canadian Journal of Economics, 46(4):1406-1430.

Bertoli, S. and Marchetta, F. (2015). Bringing it all back home-return migration and fertility choices. World Development, 65:27-40.

Boeheim, R., Horvath, G., and Mayr, K. (2012). Birthplace diversity of the workforce and productivity spill-overs in firms. WIFO Working PapersNo. 438.

Borjas, G.J. (1994). The Economics of Immigration. American Economic Review, 32:1667-1717.

Borjas, G.J. (2003). The labour demand curve is downward sloping: reexamining the impact of immigration on the labour market. Quarterly Journal of Economics, 118(4):1335-1374.

Borjas, G.J. (2015). Immigration and Globalization: A review Essay. Journal of Economic Literature, 53(4):961-974.

Borjas, G.J. (2017). The labor supply of undocumented immigrants. Labour Economics, 46: 1-13.

Burzyński, M., Docquier, F., and Rapoport, H. (2018). The changing structure of immigration to the OECD: what welfare effects on member countries? IMF Economic Review, 66(3): 564-601.

Card, D. (2009). Immigration and inequality. American Economic Review, 99(2):1-21.

Card, D (2012). Comment: The Elusive search for Negative Wage Impacts of Immigration Journal of the European Economic Association, 10(1):211-215.

Cadot, O., Carrère C., \& V. Strauss-Kahn (2011). Export Diversification: What's Behind The Hump? The Review of Economics and Statistics, 93(2):590-605.

Collier, P. (2013). Exodus: How migration is changing our World. Oxford University Press (309 p.).

di Giovanni, J. \& A.A. Levchenko \& F. Ortega (2015). A global view of cross-border migration. Journal of the European Economic Association, 13(1):168-202.

Docquier, F., Lodigiani, E., Rapoport, H., and Schiff, M. (2016). Emigration and democracy. Journal of Development Economics, 120(1):209-223.

Dorn, D. (2009). Essays on Inequality, Spatial Interaction, and the Demand for Skills. Dissertation University of St. Gallen no. 3613, September 2009.

Dustmann, C. \& T. Frattini (2014). The fiscal effects of immigration to the UK. The Economic Journal, 124(580):F593-F643. 
Feyrer, J. (2019). Trade and income: Exploiting time series in geography. American Economic Journal: Applied Economics, Forthcoming.

Fulford, S., Petkov, I., and Schiantarelli, F. (2017). Does it matter where you came from? Ancestry composition and economic performance of U.S. counties, 1850-2010. Boston College Working Papers in Economics No. 875 .

Greenberg, J. (1956) The measurement of linguistic diversity. Language, 32:109-115

Head, K., Mayer, T. and Ries, J. (2010) The erosion of colonial trade linkages after independence. Journal of International Economics, 81(1):1-14

Hunt, J. and M. Gauthier-Loisells (2010). How much does immigration boost innovation. American Economic Journal: Macroeconomics, 2:31-56

Iranzo, S. and G. Peri (2009). Migration and Trade: Theory with an application to the eastern-western European integration. Journal of International Economics, 79(1):1-19

Kahane, L., Longley, N., and Simmons, R. (2013). The effects of coworker heterogeneity on firm-level output: Assessing the impacts of cultural and language diversity in the national hockey league. The Review of Economics and Statistics, 95(1):302-314.

Lodigiani, E. and Salomone, S. (2012). Migration-induced transfers of norms: The case of female political empowerment. IRES Discussion Papers 2012-1.

Manacorda, M., A. Manning and J. Wadsworth (2012). The impact of immigration on the structure of wages: theory and evidence from Britain. Journal of the European Economic Association, 10(1):120-151

Montalvo, J.G., and Reynal-Querol, M. (2003). Religious polarization and economic development Economics Letters, 80(2):201-210.

Montalvo, J.G., and Reynal-Querol, M. (2005). Ethnic polarization, potential conflict, and civil wars. American Economic Review, 95(3):796-816.

Nickel, S. (1981). Biases in dynamic models with fixed effects. Econometrica, 49(6):1417-1426.

Oster, E. (2016) Unobservable Selection and Coefficient Stability: Theory and Validation. Journal of Business Economics and Statistics, Forthcoming.

Ottaviano, G., and Peri, G. (2006). The economic value of cultural diversity: Evidence from U.S. cities. Journal of Economic Geography, 6(1):9-44. 
Ottaviano, G and G. Peri (2012). Rethinking the Effects of Immigration on Wages. Journal of the European Economic Association, 10(1):152-197

Özden, Ç., Parsons C. R., Schiff, M., and Walmsley, T. L. (2011). Where on earth is everybody? The evolution of global bilateral migration 1960-2000. World Bank Economic Review, 25(1):12-56.

Ozgen, C., Peters, C., Niebuhr, A., Nijkamp, P. and Poot, J. (2014). Does cultural diversity of migrants employees affect innovation? International Migration Review, 48(9):377-416.

Parrotta, P., Pozzoli, D., and Pytlikova, M. (2014). Does labor diversity affect firm productivity? European Economic Review, 66:144-179.

Peri, G. (2012). The effect of immigration on productivity: evidence from the U.S. States. The Review of Economics and Statistics, 94(1):348-358

Putterman, L., and Weill, D.N. (2010). Post-1500 population flows and the long-run determinants of economic growth and inequality. The Quarterly Journal of Economics, 125(4):1627-1682.

Ruggles, S., Genadek, K., Goeken, R., Grover, J., and Sobek M. (2015). Integrated Public Use Microdata Series: Version 6.0 [Machine-readable database]. Minneapolis: University of Minnesota.

Santos Silva, J. M. C., and Tenreyro S. (2006). "The Log of Gravity". Review of Economics and Statistics, 88(4):641-658.

Sequeira, S., N. Nunn and N. Qian (2017). Migrants and the making of America: the short- and long-run effects of immigration during the age of mass migration. NBER Working Paper No. 23289

Spilimbergo, A. (2009). Democracy and foreign education. The American Economic Review, 99(1):528-543.

Spolaore E, and Wacziarg R. (2009). The diffusion of development. Quarterly Journal of Economics, 124(2):469-592.

Spolaore E, and Wacziarg R. (2015). Ancestry, Language and Culture. In: Ginsburgh V., Weber S. (eds) The Palgrave Handbook of Economics and Language. Palgrave Macmillan, London.

Storesletten, K. (2000). Sustaining fiscal policy through immigration. Journal of Political Economy, 108(2):300-323.

Suedekum, J., Wolf, K., and Blien, U. (2014). Cultural diversity and local labour markets. Regional Studies, 48(1):173-191. 